\begin{tabular}{|c|c|c|c|c|c|}
\hline \multirow{3}{*}{$\begin{array}{l}\text { 2. ECN Category } \\
\text { (mark one) } \\
\text { Supplemental } \\
\text { Direct Revision } \\
\text { Change ECN } \\
\text { Temporary } \\
\text { Standby } \\
\text { Supersedure } \\
\text { Cancel/Void }\end{array}$} & & \multicolumn{2}{|c|}{$\begin{array}{l}\text { 3. Originator's Name, Organization, MSIN, } \\
\text { and Telephone No. } \\
\text { RS Popielarczyk, TWRS } \\
\text { Engineering, A2-34, 373-5751 }\end{array}$} & $\begin{array}{l}\text { 3a. USQ Required? } \\
\text { [] Yes }[X] \text { No }\end{array}$ & \\
\hline & & \multicolumn{2}{|c|}{$\begin{array}{l}\text { 5. Project Title/No./Work Order No. } \\
\text { TWRS Safety Management Plan }\end{array}$} & $\begin{array}{c}\text { 6. Bldg./Sys./Fac. No. } \\
\text { N/A }\end{array}$ & $\begin{array}{r}\text { 7. Approval Des } \\
\text { SQ }\end{array}$ \\
\hline & & \multicolumn{2}{|c|}{$\begin{array}{l}\text { 8. Document Numbers Changed by this ECN } \\
\text { (includes sheet no. and rev.) } \\
\text { WHC-SD-WM-PLN-114, Rev. O }\end{array}$} & $\begin{array}{l}\text { 9. Related ECN No(s). } \\
\text { N/A }\end{array}$ & \\
\hline \multirow{2}{*}{\multicolumn{2}{|c|}{ 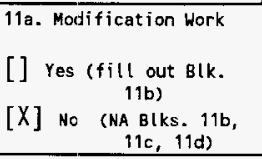 }} & \multirow[t]{2}{*}{$\begin{array}{l}\text { 11b. Work Package } \\
\text { No. } \\
\text { N/A }\end{array}$} & \multicolumn{2}{|c|}{$\begin{array}{l}\text { 11c. Modification Work Complete } \\
\text { N/A }\end{array}$} & $\begin{array}{l}\text { 11d. Restored to Original Condi- } \\
\text { tion (Temp. or Standby ECN only) } \\
\text { N/A }\end{array}$ \\
\hline & & & Cog. Engineer Signature \& Date & ire \& Date & Cog. Engineer Signature \& Date \\
\hline \multicolumn{6}{|c|}{$\begin{array}{l}n \text { the risk evaluation guidelines, } \\
\text { tation of a revised BIO plan incorporating the changes } \\
\text { ation of the development of a ISB-to-BIO transition pla } \\
\text { of the Multi-Year Program Plan fiscal guidance. }\end{array}$} \\
\hline
\end{tabular}

13a. Justification (mark one)

$\begin{array}{llllllll}\text { Criteria Change } & {[\mathrm{X}]} & \text { Design Improvement } & \text { [] } & \text { Environmental } & {[]} & \text { Facility Deactivation [] } \\ \text { As-Found } & {[]} & \text { Facilitate Const } & \text { [] } & \text { Const. Error/Omission } & \text { [] } & \text { Design Error/Omission [] }\end{array}$

-13b. Justification Details

Letter, J. E. Kinzer, RL, to A. L. Trego, WHC, "Direction for Risk Evaluation

Guidelines and Offsite Maximum Exposed Individual (MEI) Location," dated May 31, 1996.

Letter, J. E. Kinzer, RL, to A. L. Trego, WHC, "Approval of the Westinghouse Hanford Company (WHC) Safety Management PTan," 96-MSD-070, dated April 22, 1996.

14. Distribution (include name, MSIN, and no. of copies)

See attached distribution sheet.

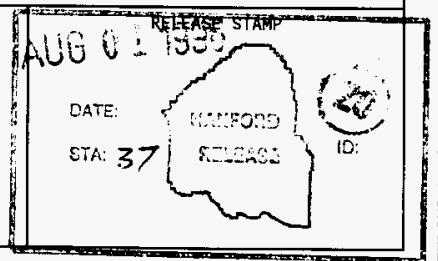




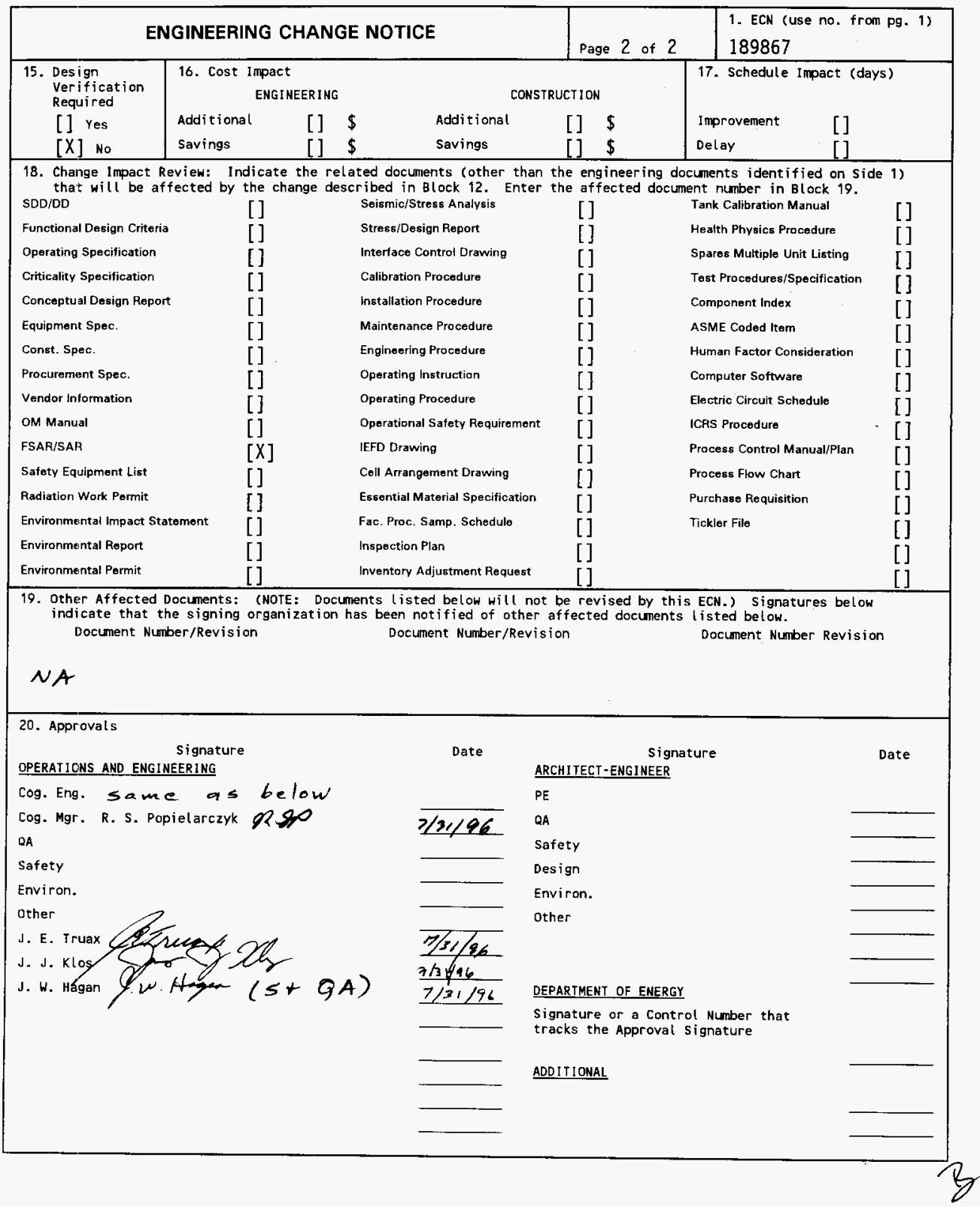




\section{TWRS Safety Management Plan}

R. S. Popielarczyk

Westinghouse Hanford Company, Richland, WA 99352

U.S. Department of Energy Contract DE-AC06-87RL10930

$\begin{array}{lll}\text { EDT/ECN: } & 189867 & \text { UC: } 510 \\ \text { Org Code: } & 74 \text { E00 } & \text { Charge Code: N1F38 } \\ \text { B\&R Code: } & \text { EW3120071 } & \text { Total Pages: } 56\end{array}$

Key Words: Safety Management Plan, BI0, FSAR, Authorization Basis

Abstract: The Tank Waste Remediation System (TWRS) Safety Management Program Plan for development, implementation and maintenance of the tank farm authorization basis is described. The plan includes activities and procedures for:
a) Updating the current Interim Safety Basis,
b) Development, implementation and maintenance of a Basis for Interim Operations,
c) Development, implementation and maintenance of the Final Safety Analyses Report,
d) Development and implementation of a TWRS information Management System for monitoring the authorization basis. TRADEMARK DISCLAIMER. Reference herein to any specific comercial product, process, or service by
trade name, trademark, manufacturer, or otherwise, does not necessarily constitute or imply its
endorsement, recommendation, or favoring by the United states Government or any agency thereof or its contractors or subcontractors.

Printed in the United States of America. To obtain copies of this document, contact: WHC/BCs Document Control Services, P.0. Box 1970, Mailstop H6-08, Richland WA 99352, Phone (509) 372-2420; Fax (509) 376-4989.
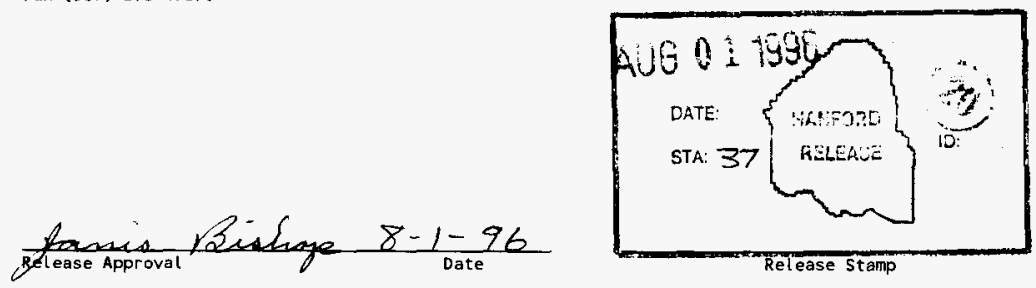

\section{Approved for Public Release}




\section{RECORD OF REVISION}

(1) Document Number

WHC-SD-WM-PIN-

114, Rev. 1

(2) Title

TWRS Safety Management Program Plan

CHANGE CONTROL RECORD

\begin{tabular}{|c|c|c|c|c|c|}
\hline & \multirow{2}{*}{ Revision } & & \multirow{2}{*}{ Description of Change - Replace, Add, and Delete Pages } & \multicolumn{2}{|c|}{ Authorized for Release } \\
\hline & & & & (5) Cog. Engr. & (6) Cog. Mgr. Date \\
\hline & $1 \mathrm{RS}$ & (7) & $\begin{array}{l}\text { Complete Revision of WHC-SD-WM-PLN- } \\
114 \text {, Rev. } 0 \text {, with the exception of } \\
\text { Sections } 4.0,5.0 \text { and Appendix A, } \\
\text { EDT } 615091,04 / 05 / 96 \quad E C N-189867\end{array}$ & Si fopulanaph & $\begin{array}{r}\text { RS Popielarczyk } \\
8 / 1 / 96\end{array}$ \\
\hline & & & & & \\
\hline & & & & & \\
\hline & & & & & - \\
\hline & & & & & \\
\hline & & & & & \\
\hline & & & & & \\
\hline & & & & & \\
\hline & & & & & \\
\hline & & & & & \\
\hline & & & & & \\
\hline & & & & & \\
\hline & & & & & \\
\hline & & & & & \\
\hline & & & & & \\
\hline & & & & & \\
\hline & & & & & \\
\hline & & & & & \\
\hline & & & & & \\
\hline & & & & & \\
\hline & & & & & \\
\hline & & & & & \\
\hline & & & & & \\
\hline & & & & & \\
\hline & & & & & \\
\hline & & & & & \\
\hline & & & & & \\
\hline & & & & & \\
\hline & & & & & \\
\hline & & & & & \\
\hline & & & & & \\
\hline & & & 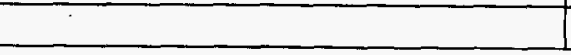 & & \\
\hline
\end{tabular}



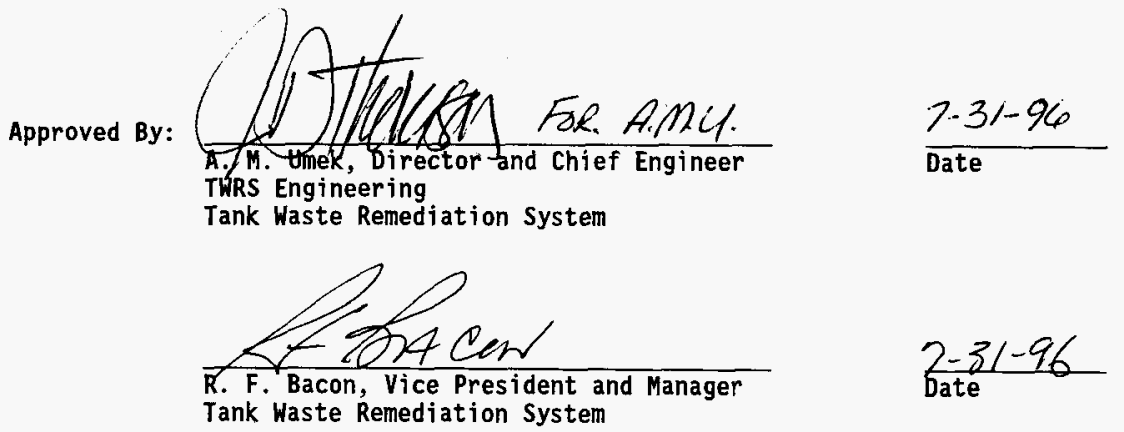


\section{EXECUTIVE SUMMARY}

This Safety Management Program Plan outlines actions that Tank Waste Remediation System (TWRS) is undertaking to address "lessons learned" and findings of a series of assessments of the TWRS authorization basis and safety management system. These assessments have identified that the central component of the current tank farm authorization basis, the Interim Safety Basis (ISB), is cumbersome and not technically integrated. In particular, controls to mitigate or prevent hazards were not derived from a comprehensive analysis of TWRS hazards, and the ISB does not support effective determinations on whether new activities or issues require authorization basis changes (i.e., the USQ process). These assessments have also pointed to significant weaknesses in the management and control of the authorization basis. Although there is generally good field compliance with technical procedures, there is limited confidence that authorization basis controls have been systematically developed and reflected in the technical procedures. A principal concern is weak configuration control throughout the safety management system.

As a result of these assessments, TWRS is taking the following corrective actions:

- Implementing safety management system components necessary to ensure consistency, clarity, formality and rigor in the development and in maintenance of the TWRS authorization basis, safety basis documents, and the technical baseline; 
- Upgrading the TWRS authorization basis to ensure there is a strong link between tank farm hazards and the corresponding controls that prevent or mitigate those hazards;

- Upgrading the process for identifying and tracking hazards and evaluating impacts of new activities or new issues (i.e., the USQ process) on the authorization basis; and

- Aligning organizational responsibilities with safety management responsibilities to ensure better safety performance.

In addition to addressing shortcomings in the tank farms authorization basis and associated safety management system components, TWRS has several near-term projects and activities that are important to carrying out the TWRS mission objectives, support implementation of the Tri-Party Agreement, and support implementation of DOE commitments to the Defense Nuclear Facilities Safety Board (DNFSB). This plan identifies the actions being undertaken to provide the tank farm authorization basis modifications needed to implement these near term projects.

The current authorization basis weaknesses and the need for near-term authorization basis modifications will be addressed using a phased and integrated approach. A Basis for Interim Operations (BI0) is being prepared using the guidance of DOE Standard 3011, Appendix A. This BI0 will replace the ISB and provide needed controls (Interim Operational Safety Requirements [IOSR]) in an expedited manner that are derived from a comprehensive assessment of TWRS hazards. The BIO will also serve as a key transition to 
implementation of the Final Safety Analysis Report (FSAR) that is under development, and provide a basis upon which an early demonstration of upgraded components of a safety management system (SMS) can be conducted. Transition plans will be prepared to guide the implementation of the BIO and the FSAR. These plans will also describe any near-term compensatory measures needed as well as reconcile the requirements of the TWRS safety management system with the BIO and FSAR.

The FSAR, Technical Safety Requirements (TSR), and DOE's safety evaluation report (SER) will form the cornerstone of the ultimate TWRS authorization basis, replacing the TWRS BIO when approved. However, since neither the TWRS BI0 or FSAR will be completed in time to support near-term project commitments, "stand alone" authorization basis packages will be prepared where practical to meet the format and content requirements of DOE Standard 3009. If a particular element of authorization basis (e.g. hazard analysis) is changed by the project, the analysis will be conducted to the level of detail required by DOE-STD-3009. If the authorization basis element is unchanged by the project (e.g. programmatic chapters), and if the existing authorization basis is adequate, it will be referenced. If the existing authorization basis is inadequate, then a level of detail of analysis consistent with the DOE- STD-3011 will be conducted. Through use of an integrated program, technical consistency between the stand alone projects, BIO and FSAR authorization package will be assured.

Upgrading the safety management system in parallel with preparing authorization basis modifications is necessary to ensure that sound authorization basis documents are prepared, and that once in place, they 
remain current. The TWRS safety management system will be upgraded by adapting functions and requirements associated with the preparation and maintenance of the BIO, FSAR and supporting documents from Savannah River Site's integrated safety management system. Those authorization basis documents that were in preparation before the availability of the new safety management system procedures, will be assessed and appropriate corrective actions implemented.

These improvements in the TWRS safety management system will be the cornerstone for the development of an integrated safety management system within TWRS. In particular, the changes underway will ensure that procedures implement key standards and requirements associated with the development and maintenance of the BI0, FSAR and their supporting documents. Moreover, these changes witl be a significant step forward in the implementation of DNFSB Recommendation 95-2 with in TWRS.

To ensure the efficacy of the safety management system, TWRS organizational responsibilities are being aligned with the functions and requirements of the upgraded safety management system. A "Chief Engineer" organization has been established and charged with the responsibility for the operation of the TWRS safety management system. Key functions within the Chief Engineer organization, are a safety and licensing group and a centralized design authority group. The Chief Engineer organization is responsible to assure implementation of corrective actions resulting from the authorization basis assessments described above. Each action will be assigned to a responsible manager and tracked to verify that resolution is achieved. 
This revision to this plan has been prepared to reflect:

- Movement, for analytical purposes, of the maximum exposed individual (MEI) location from the site boundary to the near bank of the Columbia River (Ref. 20);

.- Change in the risk evaluation guidelines (REG) (Ref. 20) ${ }^{1}$;

-- Implementation of a revised BIO plan incorporating the changes noted above;

-- Incorporation of the development of a ISB-to-BI0 transition plan; and

-- Approval of the Multi-Year Program Plan fiscal guidance.

${ }^{1}$ The DOE-HQ memorandum only applies to radiological risk evaluation guidelines. WHC will continue to apply the more conservative toxilogical risk evaluation guidelines of WHC-CM-4-46, Section 7.0, Revision 4.0. 


\section{LIST OF TERMS}

$A B$

$A C$

ADS

BIO

CIP

DNFSB

DOE

DOE-HQ

DOE-RL or RL

DST

ECN

F\&R

FDS

FSAR

GIS

HA

HLAN

IOSR

ISB

JCO

LANL

MYPP

NRC

OSD

PNNL

PRC

PUREX

RMACS

RML

RMS

SAR

SE

SEAC
Authorization Basis

Administrative Controls

Activity Data Sheet

Basis for Interim Operations

Compliance Implementation Plan

Defense Nuclear Facility Safety Board

U.S. Department of Energy

U.S. Department of Energy-Headquarters

DOE-Richland Field office

Double-She11 Tank

Engineering Change Notice

Functions and Requirements

Financial Data System

Final Safety Analysis Report

Geographical Information System

Hazard Analys is

Hanford Local Area Network

Interim Operational Safety Requirements

Interim Safety Basis

Justification for Continued Operation

Los Alamos National Laboratory

Multi-Year Program Plan

U.S. Nuclear Regulatory Commission

Operating Specification Document

Pacific Northwest National Laboratory

Plant Review Committee

Plutonium-Uranium Extraction Facility

Requirements Management and Assured Compliance System

Risk Management List

Risk Management System

Safety Analysis Report

Systems Engineering

Safety and Environmental Advisory Council 


SER
SIMS
SMS
SMP
S/RID
SRP
SSC
SST
Tri-Party Agreement
TSR
TWRS
USQ
WBS
WHC
WSRC

Safety Evaluation Report

Safety Information Management System

Safety Management System

Safety Management Program

Standards/Requirements Identification Document

Safety Requirements Project

Structures, Systems, and Components

Single-Shell Tank

Hanford Federal Facility Agreement and Consent Order Technical Safety Requirement

Tank Waste Remediation System

Unreviewed Safety Question

Work Breakdown Structure

Westinghouse Hanford Company

Westinghouse Savannah River Company 


\section{CONTENTS}

Page

1.0 INTRODUCTION . . . . . . . . . . . . . . . . . . . . . . 1

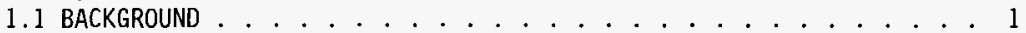

1.2 SAFETY MANAGEMENT PROGRAM MISSION AND DBJECTIVES . . . . . . . . 2

1.3 SAFETY MANAGEMENT PROGRAM PLAN PURPOSE . . . . . . . . . . . . 2

2.0 TWRS SAFETY MANAGEMENT PROGRAM * . * . . . . . 3

2.1 DEVELOP AND IMPLEMENT SAFETY MANAGEMENT SYSTEM PROCEDURES..$\quad$. 7

2.2 PREPARE BIO ...................... . . . 7

2.3 AUTHORIZATION BASIS MODIFICATION AND INTEGRATION OF PROJECTS . . 8

2.4 ISB/BIO/FSAR TRANSITION ................. . . 9

2.5 AUTHORIZATION BASIS MAINTENANCE . . . . . . . . . . . . . . . . 10

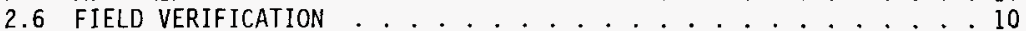

3.0 ROLES AND RESPONSIBILITIES ....................... 11

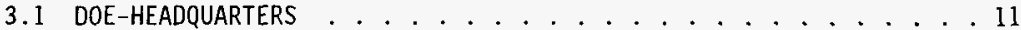

3.2 DOE RICHLAND OPERATIONS OFFICE . . . . . . . . . . . . . . . . . 11

3.3 WESTINGHOUSE HANFORD COMPANY . . . . . . . . . . . . . . . 11

3.3.1 Tank Waste Remediation System Division . . . . . . . 11

3.3.1.1 TWRS Engineering ............... . 13

3.3.1.2 Tank Farm Transition Projects . . . . . . . . . . 13

3.3.1.3 TWRS Characterization Project........ . 13

3.3.1.4 TWRS Disposal Program ............ . . 14

3.3.2 Safety and Environmental Advisory Council . . . . . . . 14

4.0 MANAGEMENT AND CONTROLS . . . . . . . . . . . . . . . . . 15

4.I BASEL INE MANAGEMENT AND CONTROL . . . . . . . . . . . . . . . I5

4.1.1 Scope, Cost, and Schedule Control . . . . . . . . . 15

4.1.2 Program Files .................... 15

4.1.3 Reports ...................... 15

4.1.4 Agreement and Commitments . . . . . . . . . . . . . 15

4.2 PROGRAM RISK MANAGEMENT . . . . . . . . . . . . . . . . . . . . . 15

5.0 QUALITY ASSURANCE . . . . . . . . . . . . . . . . . . . 17

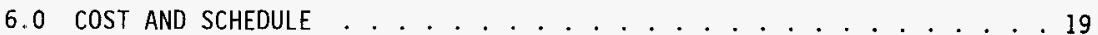

6.1 COST . . . . . . . . . . . . . . . . . . . . 19

6.2 INTEGRATED SCHEDULE . . . . . . . . . . . . . . . . . . . . . . . . . 19

7.0 REFERENCES . . . . . . . . . . . . . . . . . . . . 20

AFPENDIX A SAFETY MANAGEMENT SYSTEM FUNCTIONS AND REQUIREMENTS . . . . . A-1

AFPENDIX B SAFETY MANAGEMENT SYSTEM IMPLEMENTATION FOR A PROJECT . . . . B-l

AFPENDIX $\mathrm{C}$ BASIS FOR INTERIM OPERATION TASK PLAN . . . . . . . . . . . . c-1

APPENDIX D RISK MANAGEMENT . . . . . . . . . . . . . . . . . . . . . . . D-1

APPENDIX E COST AND SCHEDULE SUMMARIES . . . . . . . . . . . . . . E-1 


\section{TANK WASTE REMEDIATION SYSTEM SAFETY MANAGEMENT PROGRAM PLAN}

\subsection{INTRODUCTION}

\subsection{BACKGROUND}

Recent assessments and "lessons learned" have identified shortcomings in the TWRS safety management system and the TWRS authorization basis. These weaknesses include:

- The existing authorization basis is unclear, and the process for evaluating the impact of new activities or new issues (i.e. USQ process) is cumbersome. Effective configuration management has not been implemented over the technical baseline and TWRS safety documents to maintain them current.

- Tank farm controls are not linked to a comprehensive hazards analysis.

- Current safety management procedures lack sufficient formality and rigor to track hazards and requirements to structures systems, and components (SSCs).

- TWRS organizational responsibilities are not aligned to assure safety management system performance.

Several on-going TWRS projects and major activities will be completed and need to become operational before the BIO or FSAR is approved. Therefore, these projects must have their authorization basis appended to the current TWRS Authorization Basis, the ISB, via change request before they can be authorized to begin operation. Similarly, the authorization basis for these projects and activities must also be appended to the BI0 and the FSAR as they are approved. Accordingly, the authorization basis documents for these projects have been assessed for compatibility with the ISB, BIO, and FSAR.

Those projects and activities which are currently identified in the TWRS Multi-Year Program Plan to be completed in Fiscal Year 1996 or early 1997 include:

- Flammable gas justification for continued operation (JCO);

- Saltwell pumping of flammable gas single-shell tanks (SSTs);

- Rotary mode core sampling of flammable gas tanks;

- Project $W-030$ for aging waste tank ventilation upgrades;

- Project W-151 for Tank AZ-101 waste retrieval demonstration system; and

- Project W-320 for retrieval of waste from high heat Tank C-106. 


\section{I.2 SAFETY MANAGEMENT PROGRAM MISSION AND OBJECTIVES}

Using a systems engineering approach, a mission analysis was conducted for the Safety Management Program. This process identified that the TWRS Safety Management Program mission is to establish and maintain the TWRS authorization basis. To enable effective development and maintenance of the TWRS BIO, FSAR, and supporting documents, a TWRS safety management system will be developed and implemented within the TWRS Safety Management Program. These procedures will implement key provisions of the TWRS S/RID regarding the development and maintenance of the TWRS authorization basis. These near-term efforts, which focus on BIO, FSAR, and their supporting documents, will aTso serve as a significant step forward in the implementation of an integrated safety management system within TWRS that is responsive to DNFSB Recommendation $95-2$.

The program will be carried out in three major phases:

a) Provide amendments to the authorization basis to accommodate ongoing projects and activities.

b) Develop, implement and maintain the TWRS Basis for Interim Operations (BIO), to cover all identified hazards.

C) Develop, implement and maintain the TWRS Final Safety Analys is Report (FSAR).

In parallel, develop and implement the components of the safety management system necessary to develop and maintain the BIO, FSAR and their supporting documents.

\subsection{SAFETY MANAGEMENT PROGRAM PLAN PURPOSE}

The purpose of this program plan is to define the work scope, approach, schedule, management systems, and roles and responsibilities for developing and implementing. the TWRS Safety Management Program. The work scope identified addresses the lessons learned from the assessments of the TWRS authorization basis and safety management system. 


\subsection{TWRS SAFETY MANAGEMENT PROGRAM}

The mission of the TWRS Safety Management Program is to establish and maintain the TWRS authorization basis. The current authorization basis for TWRS is primarily captured in Chapter 6 of the Hanford Tank Farm Facilities Interim Safety Basis (ISB), WHC-SD-WM-ISB-001, which is not fully compliant with current DOE Orders. Furthermore, the TWRS Safety Management Program includes responsibility for the development of the TWRS safety management system described in this plan.

A well defined authorization basis is one that is compliant with applicable DOE Orders 5480.22 and 5480.23, that enables the following:

- DOE approval of all authorization basis documents as specified in DOE Order 5480.23;

- Identification of allowable and restricted activities and/or the basis on which to evaluate said activities;

- Hazards analyses which provide the base for controls, limits and restrictions;

- Safety Structures, Systems, and Components (SSCs) consistent with the hazards and accident analyses;

- Current facility descriptions sufficient to support the safety SSCs and controls established in the authorization basis under configuration control; and

- Capability of trained USQ evaluators to successfully deal with the complexity of the authorization basis documentation.

The first step to upgrade the TWRS authorization basis is amending the current authorization basis to accommodate near-term projects and activities. The second step includes the development of a TWRS BIO, with the corresponding Interim Operational Safety Requirements (IOSR). The BIO will be compliant with DOE Standard 3011, Appendix A and derive controls from a comprehensive hazard analysis. The third step is the development and full implementation and maintenance of the TWRS Final Safety Analysis Report (FSAR) and fully implemented Technical Safety Requirements (TSR). The FSAR and TSR are being developed under the Tank Waste Remediation System Final Safety Analysis Report Project Plan, WHC-WM-PLN-113. In parallel, WHC will develop and implement the components of a safety management system necessary to develop and maintain the BIO, FSAR and their supporting documents.

To support these activities, components of a safety management system will be developed and implemented. The system will include the following:

- A formal Westinghouse Hanford Company (WHC) process for the development, approval, maintenance and control of the authorization basis documents, including DOE approval. 
- A well defined process to maintain the authorization basis, including an improved USQ process.

- A disciplined process to assure necessary changes to procedures and design documentation are made to reflect changes made to the authorization basis.

The near-term safety management system development efforts will cover all necessary procedures and training for systematic implementation of the TWRS BIO, FSAR and their supporting documents. Appendix A provides a description of the TWRS safety management system functions and requirements currently being developed.

The scope of work under the cognizance of the Safety Management Program has been divided into several pieces. Figure 2.1 describes the overall work breakdown structure. The subset of this work that is being funded and managed within the scope of this plan is:

- Develop and implement Safety Management System/Procedures

- Prepare BI0

- Authorization Basis Modification and Integration of Projects

- ISB/BI0/FSAR Transitions

- Authorization Basis Maintenance

- Field Verification

Additional scope of work under WBS elements as listed below, are under the Safety Management Program, but their field implementation will be addressed in other TWRS plans.

- Self Assessments/Corrective Actions

- IOSR, OSD, \& Procedures Implementation

- Plant Review Committee

- USQ Process Control

- Establish and Implement Technical Baseline

- FSAR Preparation

- Authorization Basis Baseline Development and Management

Figure 2.2 describes the overall logic for the phased and integrated approach being undertaken within the Safety Management Program.

To facilitate the implementation of this plan and achieve the longerterm objectives of the Safety Management Program, a TWRS Chief Engineer, a Safety and Licensing organization, and a Design Authority organization have been established. These organizations and individuals will be accountable for the TWRS Safety Management Program and chartered with responsibility to establish and maintain the TWRS authorization basis and safety basis. 


\section{Safety Management Program Work Breakdown Structure}

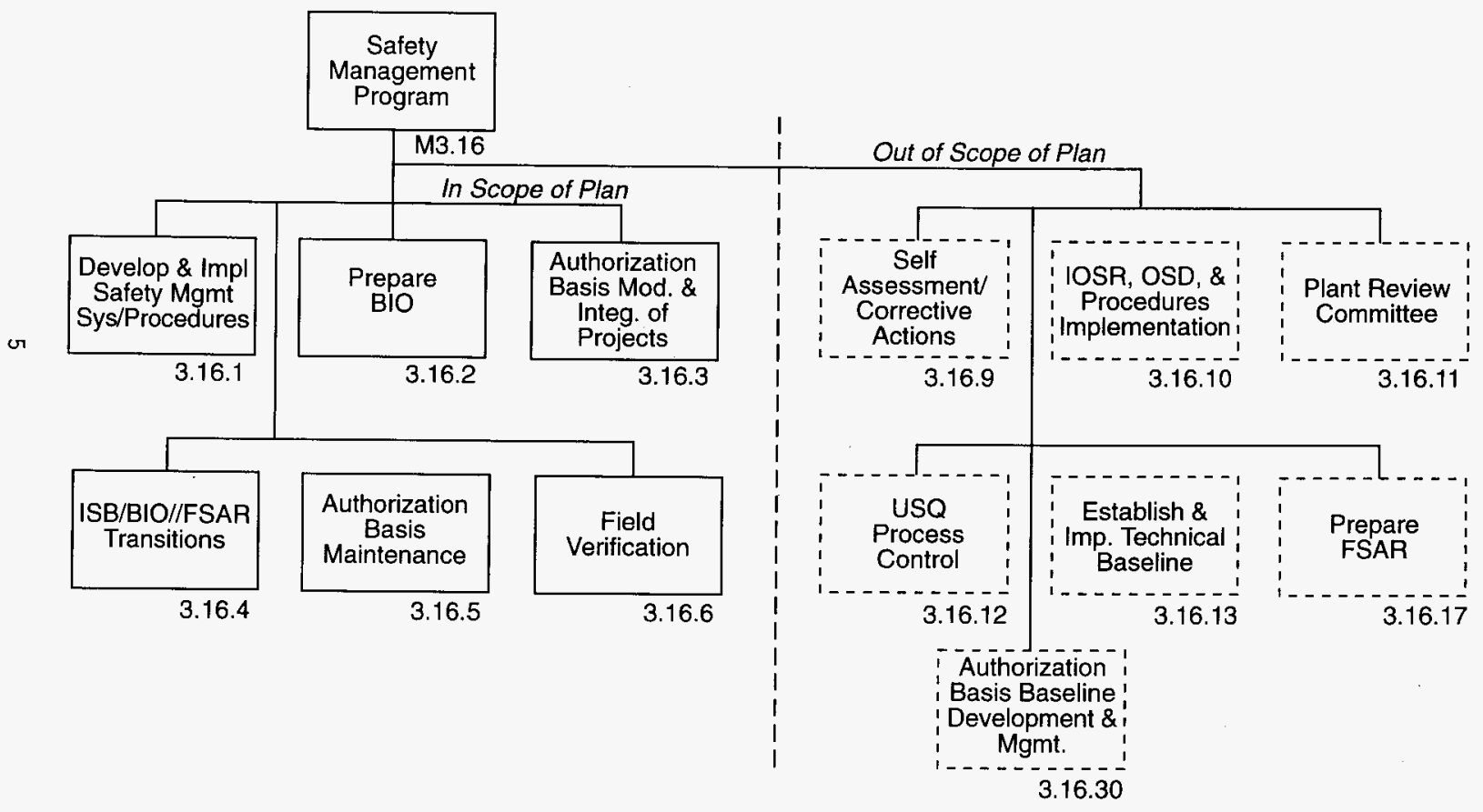

BTF070096.13 (7/29/96) 
Figure 2.2 Safety Management Program Logic Diagram

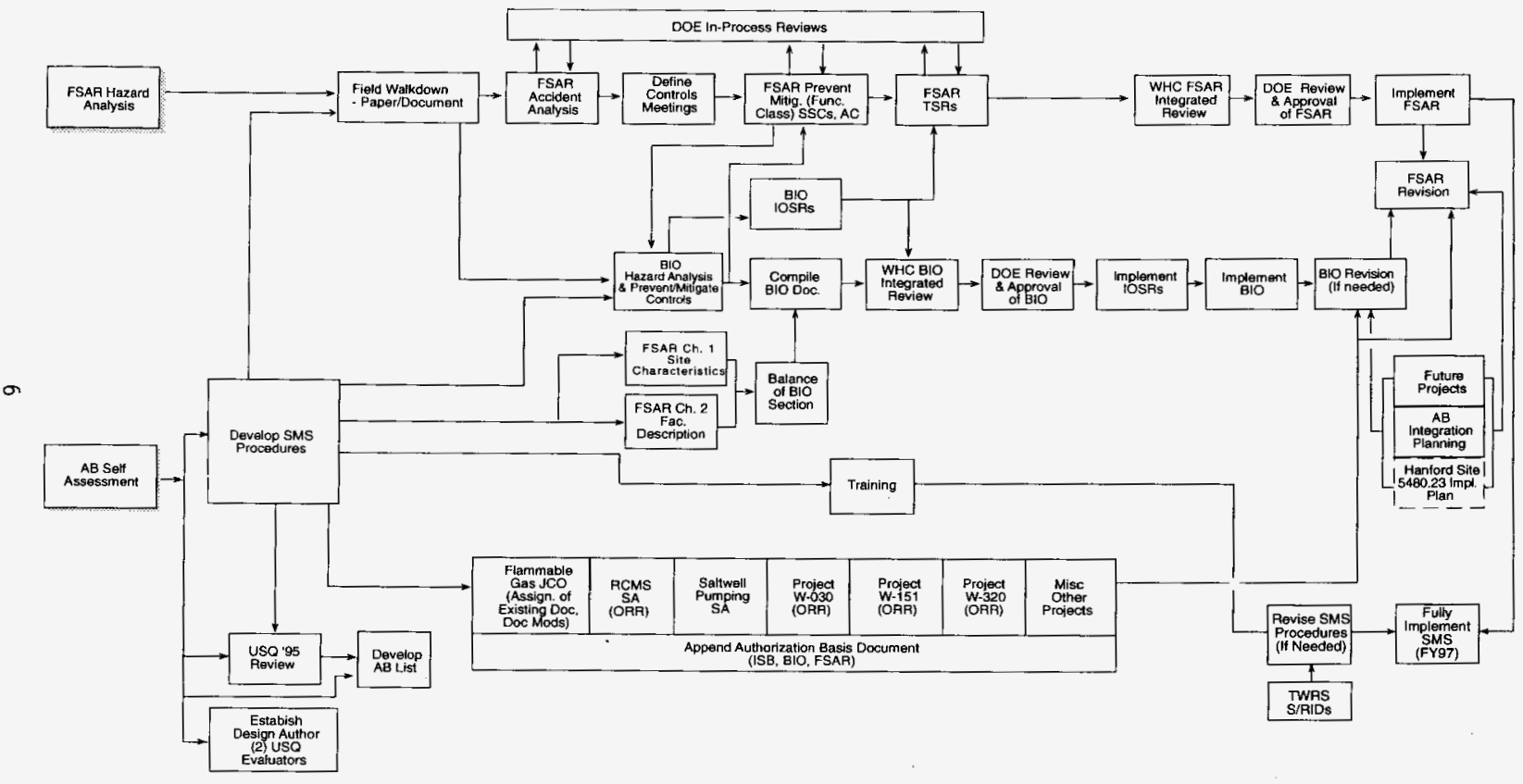




\subsection{DEVELOP AND IMPLEMENT SAFETY MANAgEMENT SYSTEM PROCEDURES (WBS 3.16.1)}

The TWRS safety management system will be implemented through procedures for activities required to develop, implement, and maintain the authorization basis documents, safety basis documents, and technical baseline documents. The procedures will specify content, format, and approval requirements for basel ine documents. A change control process will be established to ensure that any proposed changes will be properly reviewed and approved prior to implementation. This review will include a requirement to identify and address all impacts to other documents and activities.

Training needs associated with these procedures will be identified and training packages will be issued. Training of the TWRS personnel will be provided by those organizations responsible for implementing the safety management system.

Existing WHC and Westinghouse Savannah River Company (WSRC) procedures will be assessed to determine their applicability to satisfy the functions and requirements of the Safety Management System. Existing WHC and TWRS procedures will be reviewed, and changes implemented as needed. Procedures selected from WSRC wi11 be revised and integrated as appropriate into the TWRS procedure system. New procedures will only be developed when an existing procedure does not meet the needs of the TWRS safety management system.

The procedures will incorporate and implement relevant portions of the TWRS S/RID. Future efforts in the development of the TWRS integrated safety management system in conjunction with the completion of the TWRS Phase I and Phase II S/RID assessment will ensure complete implementation of the TWRS S/RID in procedures.

Del iverables:

Issued Safety Management Program procedures - Complete. Issued Training Packages.

\subsection{PREPARE BIO (WBS 3.16.2)}

A Basis for Interim Operations (BIO) and associated Interim Operational Safety Requirements (IOSR) will be developed based on the hazard analyses and to the extent possible the accident analysis performed under the FSAR Project Plan. The BIO will provide a sufficiently formal authorization basis to enable early implementation of the safety management system. The BI0 will also enable early implementation of a full set of controls based on a comprehensive hazard analysis. Moreover, the BIO will be a key transitional step from the ISB to the rigor of the FSAR. The TWRS BIO will be developed using the risk evaluation guidelines identified in the April 4, 1996, memorandum from R. Guimond, HQ, to Manager, RL, “Interim Radiological Dose Acceptance Criteria For The Hanford Tank Farms Safety Analysis," (Ref 22). The TWRS BIO will use the near-bank of the Columbia River as the potentially nearest point of uncontrolled public access and risk evaluation guidelines as directed in Reference 20. Appendix C provides a plan for the BIO development. 
Del iverables:

Basis for Interim Operation - for DOE approval.

Interim Operational Safety Requirements - for DOE approva1.

Note:

Other deliverables related to the development of the BIO are provided in the Validation WBS element, Section 2.8.

\subsection{AUTHORIZATION BASIS MODIFICATION AND INTEGRATION OF PROJECTS (WBS 3.16.3)}

A number of ongoing TWRS projects and activities are critical to the success of the TWRS mission and are scheduled to be completed and operationat before the BIO or FSAR are approved and implemented. These projects will be incorporated into future FSAR revisions; therefore, their authorization basis documents must be developed to allow for that incorporation. If a particular element of authorization basis (e.g. and accident hazard analys is) is changed by the project, the analysis will be conducted to the level of detail required by DOE-STD-3009. If the authorization basis element is unchanged by the project (e.g. programmatic chapters), and if the existing authorization basis is adequate, it will be referenced. If the existing authorization basis is inadequate, then a level of detail of analysis consistent with the DOE-STD3011 will be conducted. These documents will be added to the current authorization basis, and will remain in effect when the BIO and FSAR are issued.

The safety documentation for these projects have been reviewed for consistency with the BIO and FSAR analyses, with each other, and with the safety management system content requirements. Upgrades to these safety documents will be performed as necessary.

TWRS projects have also been reviewed to ensure consistency with revised DOE guidance on the MEI location and risk evaluation guidelines. DOE-RL letter, "Direction For Risk Evaluation Guidelines And Offsite Maximum Exposed Individual (MEI) Location," (Ref 20) ${ }^{2}$ directs TWRS safety analyses initiated for projects prior to April 4, 1996, to use the risk evaluation guidelines contained in DOE-RL letter of June 14, 1995, "Risk Acceptance Criteria For Tank Farm Operation" (Ref 21). TWRS safety analyses that start after April 4, 1996, WHC are to use the risk evaluation guidelines in DOE-HQ memorandum of Apri1 4, 1996, from R. Guimond to the Manager, RL, "Interim Radiological Dose Acceptance Criteria For The Hanford Tank Farms Safety Analys is," (Ref 22).

DOE-RL (Ref 20) also directed that the near bank of the Columbia River must be considered as potentially the nearest point of uncontrolled public access. TWRS safety analyses initiated prior to March 5, 1996, are to continue using the Hanford Reservation Boundary for the location of the MEI. Where required, project safety analyses will be revised to move the MEI to the

${ }^{2}$ The DOE-HQ memorandum only applies to radiological risk evaluation guidelines. WHC will continue to apply the more conservative toxilogical risk evaluation guidelines of WHC-CM-4-46, Section 7.0, Revision 4.0. 
near-bank of the Columbia River during the first annual update or when incorporated into the TWRS BIO and FSAR. For project safety analyses initiated after March 5, 1996, the location of the MEI will be defined as the near-bank of the Columbia River.

Project safety analyses will have parametric studies completed to provide early indication of any significant control requirement changes that may be forthcoming as a result of the change in MEI location or risk evaluation guideline.

It is assumed that changes to the documentation will be funded by the activity or project. Prior to project turnover, change requests will be processed to incorporate these activities into the current TWRS Authorization Basis. This plan includes validation of the incorporation of any identified. changes to the project documentation.

Authorization basis document requirements for new projects will be identified during project development by the Safety and Licensing Group. Appendix B provides a sample process for implementing the authorization basis amendment process on a project.

Deliverables:

Project assessments -- Complete.

\subsection{ISB/BIO/FSAR TRANSITIONS (WBS 3.16.4)}

The TWRS BIO is being developed in parallel with the development of the Safety Management System. Furthermore, because the BIO will be based upon a comprehensive hazard analysis, significant differences in the application of controls or SSC classification may result. The BIO will be reconciled against the requirements of the safety management system. As they are developed, the hazard analysis and control suite (IOSR) of the BIO will be compared with the current IOSR. If the comparison of the new IOSR identifies significant deficiencies, immediate compensatory measures will be implemented to ensure protection of the workers, public and the environment. In addition, a transition plan will be prepared to guide the implementation of the BIO and to document compensatory measures in effect until the BIO controls are implemented.

The FSAR and TSR are being developed in parallel with the development of the safety management system procedures. After development of the safety management system, a reconciliation of the FSAR and TSR with the safety management system will be conducted.

Following development of the FSAR and associated TSR, the implementation of the controls will be conducted under this plan. This will include the development of implementing documents for the controls, provision of compensatory measures for those controls that can not be immediately implemented, and the issuance of a transition plan for those controls and compensatory measures. 
Future revisions of this plan will address specific strategies for incorporating currently stand-alone safety analysis (e.g., 242-A) into the future revisions of the FSAR.

Deliverables:

ISB/BIO Transition Plan.

BIO/FSAR Transition PIan.

\subsection{AUTHORIZATION BASIS MAINTENANCE (WBS 3.16.5)}

Maintenance of the TWRS authorization basis includes activities which support the following: (a) assurance of technical quality and consistency of USQ evaluations, (b) definition of the authorization basis, (c) change control and revision of authorization basis documents, and (d) implementation of the authorization basis.

A list of the current TWRS Authorization Basis documents will be developed and issued.

An assessment will be performed to verify the implementation of controls identified in the authorization basis documents. A cross-reference will be developed and implemented to link authorization basis requirements with the documents credited for implementing them.

Deliverables:

List of authorization basis documents - Complete.

List providing cross-reference from requirements to implementing documents - Complete.

\subsection{FIELD VERIFICATION (WBS 3.16.8)}

In conjunction with the FSAR hazards analysis, a field validation will be performed to confirm the input information and assumptions used in the analysis. This validation process, including both field walkdowns and documentation reviews, will document the hazardous material inventories (form, location, type and amount), potential accident initiators with frequencies, ard potential SSCs to be used for controls. All work is being conducted under ar approved task plan until the Safety Management System procedures are developed under Section 2.1 of this plan. All documents will be placed under configuration control in accordance with those procedures.

The Hazards Analysis will be revised, if required, based on the results of the validation.

Deliverables:

Revised hazards analysis for the BIO and FSAR

Configuration controlled walkdown results 


\subsection{ROLES AND RESPONSIBILITIES}

The roles and responsibilities for developing and implementing the TWRS Safety Management Program are outlined in the following sections.

\subsection{DOE-HEADQUARTERS}

DOE-HQ will monitor the development and implementation of the TWRS BIO and FSAR in accordance with the memorandum of agreement with RL. DOE-HQ will approve the FSAR.

\subsection{DOE RICHLAND OPERATIONS OFFICE}

RL is responsible for the approval of the TWRS Safety Management Program Plan and for ensuring site contractor execution of the plan. RL will also review and approve changes to the TWRS Authorization Basis, including review and approval of the BIO prior to implementation by WHC. RL will monitor the implementation of the Safety Management Program through status meetings and day-to-day interactions with the WHC management staff, including updates of any $\mathrm{RL}$ safety management $\mathrm{plans}$ outlined in Wagoner, $1996 .^{3}$

\subsection{WESTINGHOUSE HANFORD COMPANY}

WHC will develop and implement the TWRS Safety Management Program including development, implementation, upgrade, and maintenance of the TWRS Authorization Basis. This process will use existing WHC management control systems that implement the Quality Assurance (QA) Program requirements of 10 CFR 830.120 , and the WHC requirements for development of safety analyses.

\subsubsection{Tank Waste Remediation System Division}

The TWRS Division is responsible for developing, implementing, and managing the TWRS Safety Management Program, Technical Baseline, and Authorization Basis and for operating the tank farms. The division includes the departments discussed in following subsections.

The TWRS organizational structure for managing the activities defined in this plan is shown in Figure 3-1. Major elements of the organizational structure are described in the following subsections.

3Wagoner, J.D. “DOE, Richland 0perations Office (RL), P1 an for Improved Authorization Basis and Procedure Compliance at Hanford." Memorandum to T. P. Grumbly February 17, 1996, D0E-RL, Richland, Washington. 
Figure 3.1

TWRS Safety and Licensing Organization

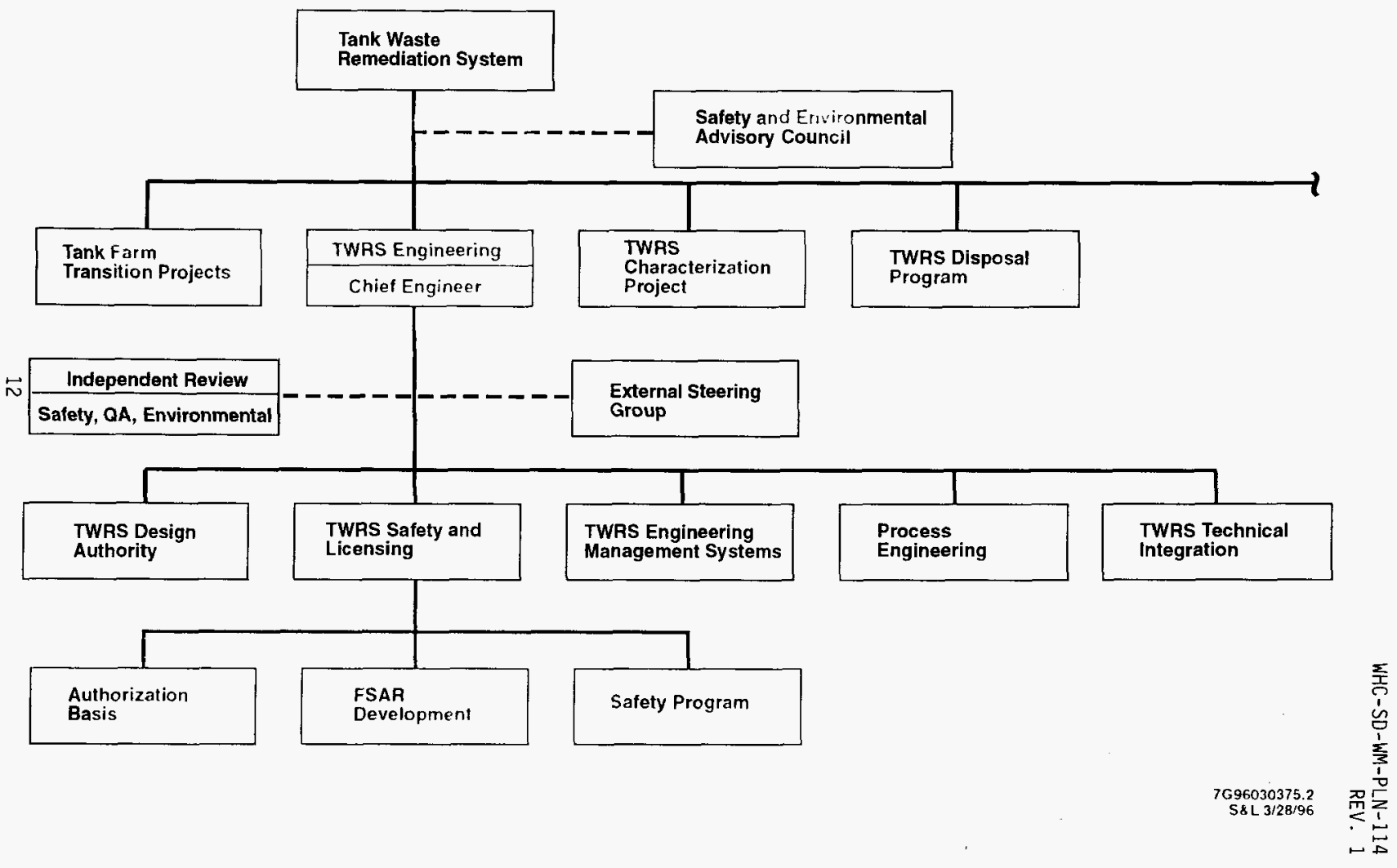




\subsubsection{TWRS Engineering}

The TWRS Chief Engineer, the Director of the TWRS Engineering, is responsible for developing the TWRS Safety Management Program, Authorization Basis, and safety basis. This organization also has responsibility to achieve consistency in the implementation of the Safety Management System and maintenance of the TWRS Authorization Basis.

The Safety and Licensing Group has been established to direct the TWRS Safety Management Program, establish safety and licensing policy, prepare and issue the TWRS Safety Analysis documentation including BI0 and IOSR documents, and the FSAR and TSR documents. The Safety and Licensing Group also has responsibility for integrating activities to resolve the safety issues related to the Hanford Tank Farms with those being undertaken to upgrade the authorization basis. The Safety and Licensing manager reports to the Director of Engineering and will ensure that all work delineated in this plan is completed within established cost and schedule baselines and that the documents produced are in compliance with applicable requirements.

The TWRS design authorities are responsible for final acceptability of, and approving changes to, TWRS structures, systems, and components (SSCs), and its technical baseline.

The WHC TWRS Safety and Quality Assurance representatives are responsible for conduct of independent reviews of safety, health, and quality affecting functions. The nuclear safety representative will coordinate safety basis reviews conducted in the following subject areas: (1) nuclear safety, (2) fire protection, (3) radiological control, and (4) industrial safety and industrial hygiene. Environmental compliance reviews will be conducted through the assigned environmental compliance officers. TWRS Quality Assurance will conduct QA reviews.

\subsubsection{Tank Farm Transition Projects}

Tank Farm Transition Projects are responsible for operating the tank farms and evaporator in compliance with the approved TWRS authorization basis. Tank Farm Transition Projects staff members will fill key leadership positions on the FSAR Project and Authorization Basis teams to establish the technical bases of the tank farm facilities. Tank Farm Transition Project staff members will also be integrally involved in the development, review and approval of changes to the Authorization Basis for any activity associated with the Tank Farm facilities and project activities.

\subsubsection{TWRS Characterization Project}

The TWRS Characterization Project is responsible for operating the tank waste characterization systems and equipment in compliance with the approved TWRS authorization basis for the purpose of characterizing the tank waste contents. Key individuals from the Project will participate in the development, review and approval of changes to the Authorization Basis associated with waste characterization activities. 


\subsubsection{TWRS Disposal Program}

The TWRS Disposal Program is responsible for definition, development and design of disposal alternatives in support of privatization. At present, the Program is responsible for design and approval of the C-106 and AZ-101 retrieval activities

\subsubsection{Safety and Environmental Advisory Council}

The Safety and Environmental Advisory Council, through the Tank Waste Remediation Subcounci?, is responsible for conduct of final integrated reviews of safety and environmental affecting documentation, such as the FSAR, BIO, $J C O s$ and any changes thereto, to provide company-level assurance that al 1 important factors have been adequately addressed. The subcouncil's findings or concerns are reported to TWRS senior management for resolution of any issues prior to the release of such documents. 


\subsection{MANAGEMENT AND CONTROLS}

\subsection{BASELINE MANAGEMENT AND CONTROL}

Baseline management and control of the Safety Management Program have been implemented in accordance with WHC-CM-2-5, Management Control System. This plan defines the scope, schedule, and cost baseline for the TWRS Safety Management Program. The baseline will be established in a formal change request package to the TWRS Multi-Year Program Plan (MYPP). Modifications to this plan will be implemented using appropriate change control procedures.

\subsubsection{Scope, Cost, and Schedule Control}

Schedules identify the activities upon which the budget is based. These schedules identify the logical relationships among program activities that are developed to define the critical path and establish baseline commitments. These schedules will aid managers in tracking document status and in identifying issues for early resolution.

Managers track and controt their costs by using the Financial Data System (FDS). Cost account information will be reviewed by the project managers weekly.

\subsubsection{Program Fjles}

Official program files are maintained for documentation, plans, correspondence, and related administrative records.

\subsubsection{Reports}

The Safety and Licensing manager prepares bi-weekly status reports addressing major accomplishments and critical issues. These reports are provided to RL. The Safety and Licensing Manager provides monthly cost/schedule performance analysis reports to RL and the WHC staff.

\subsubsection{Agreement and Commitments}

Any changes to the program baselines will be documented, approved, and funded via the change control process prior to implementation.

\subsection{PROGRAM RISK MANAGEMENT}

Program risk management techniques are applied by means of systematic identification, assessment or analysis, and handling of risks to the program technical, cost, and schedule bases. The risk management list that has been developed identifies critical risks and mitigating actions, and is used to track risk mitigation actions regularly and systematically. Risks (e.g., assumptions, external events, major uncertainties) that the program faces are identified in the risk management list. The likelihood that the risks will impact the program, what the potential impacts would be, and the severity of 
the consequences are identified, and management actions and responsibilities are specified.

The risk management 1 ist will be modified as work proceeds. Program management reviews the list at least biweekly. These reviews will focus on changes to the risk management list, risks for which decisions regarding risk management actions are required, and any risks with "critical" status (major or immediate threat to the program). The risk management list is reviewed with RL at the biweekly meetings.

The risk management 1 ist in Appendix $D$ provides a description of the programmatic risk process and a sample risk management 1 ist that provides an assessment of risks currently being tracked and managed, including those relating to the development of this plan. 


\subsection{QUALITY ASSURANCE}

The major portion of work to be accomplished as described in this program plan will be performed in compliance with the TWRS quality assurance program, with a few program specific requirements in sections 2.0 and 3.0 and appendix A. Together the TWRS QA plan and this program plan constitute the QA plan for the TWRS Safety System Program. The TWRS QA plan is documented in WHC-SP.131, Westinghouse Hanford Company Quality Assurance Program and Implementation Plan.

The following documents describe the TWRS Quality Assurance program for the Safety Management Program activities affecting quality. The TWRS Vice President has issued WHC-CM-6-34, TWRS Quality Management Plan which describes how TWRS is organized and managed to accomplish its mission. WHC-CM-4-2, Quality Assurance Manual, describes the WHC site quality assurance program which TWRS must implement. WHC-CM-6-50, TWRS Quality Assurance, provides facility specific supplemental information. Figure 5.1 i1lustrates the manual and procedure structure.

The Safety Management Program Plan contains additional details of organization and responsibilities which supplement the WHC-CM-6-34, Quality Management Plan.

There exist implementing manuals and procedures for the design work, document controls, records management, etc. including SAR, PSAR, and FSAR preparation and issue. Therefore, most of the System Management Program activities will be performed in accordance with existing implementing procedures described in the manuals discussed above. Program unique quality assurance activities are integrated into this program management plan as described above, especially in sections 2.0 and 3.0 and appendix $A$.

The incorporation of the Safety Management Program quality assurance plan into the Safety Management Program Plan makes the quality assurance requirements more visible to the program performers and promotes compliance with the requirements. 
Figure 5.1 TWRS Quality Assurance Requirements/Manual Structure

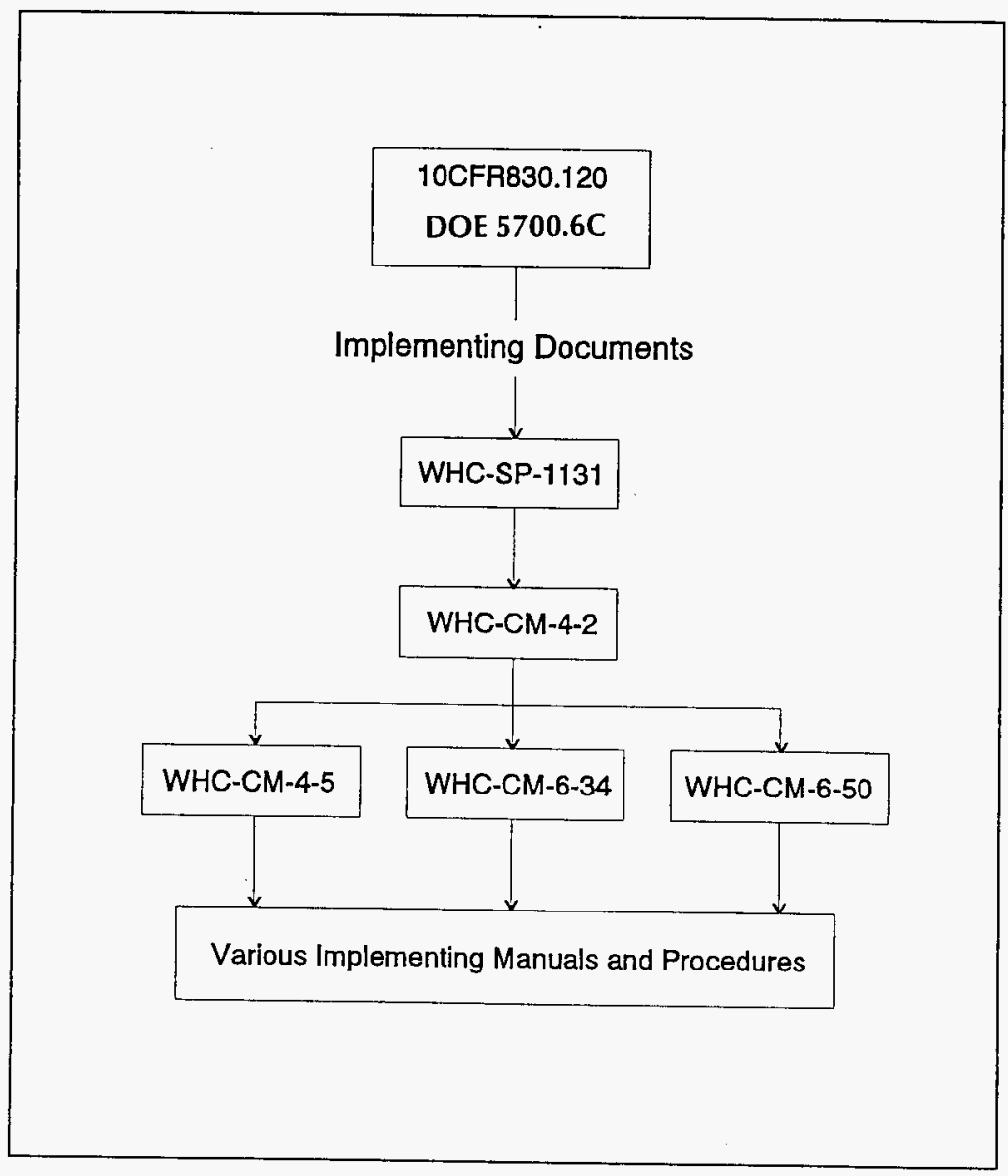




\subsection{COST AND SCHEDULE}

\section{$6.1 \operatorname{cosT}$}

The summary cost estimate at the DOE WBS controlled level is shown in Table 6-1. Detailed costs are presented at Appendix E.

Table 6-1

TWRS Safety Management Program

Estimated Cost $(\$ 000)$

\begin{tabular}{||l|l|c|}
\hline \hline $3.16 \quad$ Safety Management Program and Authorization Basis Upgrades \\
\hline 3.16 .1 & $\begin{array}{l}\text { Develop and Implement Safety Management } \\
\text { System/Procedures }\end{array}$ & $\$ 650$ \\
\hline 3.16 .2 & Prepare BI0 & 620 \\
\hline 3.16 .3 & $\begin{array}{l}\text { Authorization Basis Modification \& Integration of } \\
\text { Projects }\end{array}$ & 360 \\
\hline 3.16 .4 & ISB/BI0/FSAR Transition & 110 \\
\hline 3.16 .5 & Authorization Basis Maintenance & 320 \\
\hline 3.16 .8 & Field Verification & $\$ 2,740$ \\
\hline
\end{tabular}

\subsection{INTEGRATED SCHEDULE}

The DOE controlled milestones are provided below. The integrated schedule for tracking progress against the baseline is provided in Appendix $E$ for information only.

Key project deliverables:

- Provide List of Current Authorization Basis Documents

Apri1 15, 1996

- Complete Hazard ID and Configuration Verification June 7, 1996

- Implement Operational TWRS, AB Tracking System June 28, 1996

- Issue Interim $0 \mathrm{SR}^{\prime} \mathrm{s}$ for RL Approval

August 30,1996

- Issue Basis for Interim Operation for RL Approval September 30,1996

- Implement Operational TWRS Safety Management System 


\subsection{REFERENCES}

1. U.S. Department of Energy, "Technical Safety Requirements," DOE Order 5480.22 , Washington D.C., February 25, 1992.

2. U.S. Department of Energy, "Nuclear Safety Analysis Reports," DOE Order 5480.23, Washington D.C., Apri1 10, 1992.

3. U.S. Department of Energy, "Guidance for Preparation of DOE Orders 5480.22 (TSR) and 5480.23 (SAR) Implementation Plans, "DOE-STD-3011-94, Washington D.C., November 1994.

4. Westinghouse Hanford Company, "Hanford Site Tank Farm Faci1ities Interim Safety Basis," WHC-SD-WM-ISB-001, Rev. 0, Richland, Washington, August, 1993.

5. U.S. Department of Energy, "Hazard Categorization and Accident Analysis Techniques for Compliance with DOE Order 5480.23, Nuclear Safety Analysis Reports," DOE-STD-1027-92, Washington D.C., December 1992.

6. Westinghouse Savannah River Company, "Functional Classification of Safety Class and Safety Significant Structures, Systems, and Components, "Manual E7, Procedure 2.25, Aiken, South Carolina, February 1, 1995.

7. Westinghouse Hanford Company, "Single-Shel1 Tank Interim Operational Safety Requirements," WHC-SD-WM-0SR-005, Rev. 08, Richland, Washington, April 3, 1995.

8. Westinghouse Hanford Company, "Double-She11 Tank Interim Operational Safety Requirements," WHC-SD-WM-0SR-016, Rev. 08, Richland, Washington, April 3, 1995.

9. Westinghouse Hanford Company, "Aging Waste Facility Interim Operational Safety Requirements," WHC-SD-WM-OSR-004, Rev. 08, Richland, Washington, Apri1 3, 1995.

10. Westinghouse Hanford Company, “Qual ity Assurance Manual," WHC-CM-4-2, Release 83, Richland, Washington, February 15, 1996.

11. Westinghouse Hanford Company, "Implementation Plan for DOE Orders 5480.21, 5480.22, and 5480.23," Correspondence No. 9257875, Richland, Washington, October 28, 1992.

12. U.S. Department of Energy, "Preparation Guide for U.S. Department of Energy Nonreactor Nuclear Facility Safety Analysis Reports," DOE-STD3009-94, Ju7y 1994.

13. Westinghouse Savannah River Company, "Safety Document Integrated Work Process Guideline and Methods (U)," WSRC-RP-95-001, Rev. 0, Aiken, South Carolina, November 30, 1995.

14. Title 10, Code of Federal Regulation 830.120, "Quality Assurance". 
15. U.S. Department of Energy, "Quality Assurance", DOE 5700.6, Rev. C.

16. Westinghouse Hanford Company, "Westinghouse Hanford Company Quality Assurance Program and Implementation Plan", WHC-SP-1131, Rev. 0, Richland, Washington, dated March 1995.

17. Westinghouse Hanford Company, "Quality Assurance Qualifications and Instructions", WHC-CM-4-5.

18. Westinghouse Hanford Company, "TWRS Quality Management Plan", WHC-CM-6-34, Rev. 0, dated August 1995.

19. Westinghouse Hanford Company, "TWRS Quality Assurance", WHC-CM-6-50.

20. Letter from J. Kinzer, RL, to President, WHC, "Direction For Risk Evaluation Guidelines And Offsite Maximum Exposed Individual (MEI) Location," 96-WSD-062, dated May 31, 1996.

21. Letter from A. Sidpara, RL, to President, WHC, "Risk Acceptance Criteria For Tank Farm Operation," \#9502999, dated June 14, 1995.

22. Memorandum from R.Guimond, HQ, to Manager, RL, "Interim Radiological Dose Acceptance Criteria For The Hanford Tank Farms Safety Analysis," dated April 4, 1996. 


\section{APPENDIX A SAFETY MANAGEMENT SYSTEM FUNCTIONS AND REQUIREMENTS}

Figure A-1 is a functional diagram of the Safety Management System. The four subsystems are the Technical Baseline Management System, the Risk Management System, the Authorization Basis Management System, and the Site Safety Management Programs. Each of these subsystems is discussed below.

\subsection{TECHNICAL BASELINE MANAGEMENT SYSTEM FUNCTIONS AND REQUIREMENTS}

The Technical Baseline Management System is required to manage and maintain current the documents related to: (1) the configuration of the facility structures, systems, and components (SSCs); (2) the site description and characteristics; (3) the inventory of hazardous materials present within the facility; (4) the facility requirements; and (5) the safety basis documents that support the authorization basis of the facility.

\subsection{TWRS SSC Management}

The SSC configuration is defined in terms of engineering documents ipcluding drawings, design analyses, design requirements and criteria, equipment lists, and vendor information. The SSC Management function must identify SSCs important to safety, maintain the documents describing the configuration, provide information about the status of items under configuration control, and provide a process to evaluate and implement proposed changes to the SSCS and their related documents. Changes in the information related to the SSC configuration must be communicated to the following functions: Risk Identification, Establish Prevention/Mitigation, Authorization Basis Control, and Site Safety Management Programs.

\subsection{SITE DESCRIPTION MANAGEMENT}

Site description information includes meteorological, seismic, lightning, flood, volcanic, and geophysical data. The Site Description Management function must include a process to identify which data are important to the Safety Management System, specify appropriate media for the documentation and retrieval of the data, and specify the processes to control changes to the site description data accepted into the Technical Baseline Management System. Changes in the site description must be communicated to the following functions: Risk Identification, Authorization Basis Control, and Site Safety Management Programs.

\subsection{HAZARDOUS MATERIAL INVENTORY TRACKING}

The Hazardous Material Inventory Tracking function must provide a process to identify and document important attributes (type, quantity, form, process or storage condition, location) of the hazardous materials associated with the TWRS facilities. This information will be used to determine the facility hazard category and resulting authorization basis documentation requirements. Changes in the hazards information must be communicated to the 
Figure A-1

\section{TWRS Safety Management System Functions}

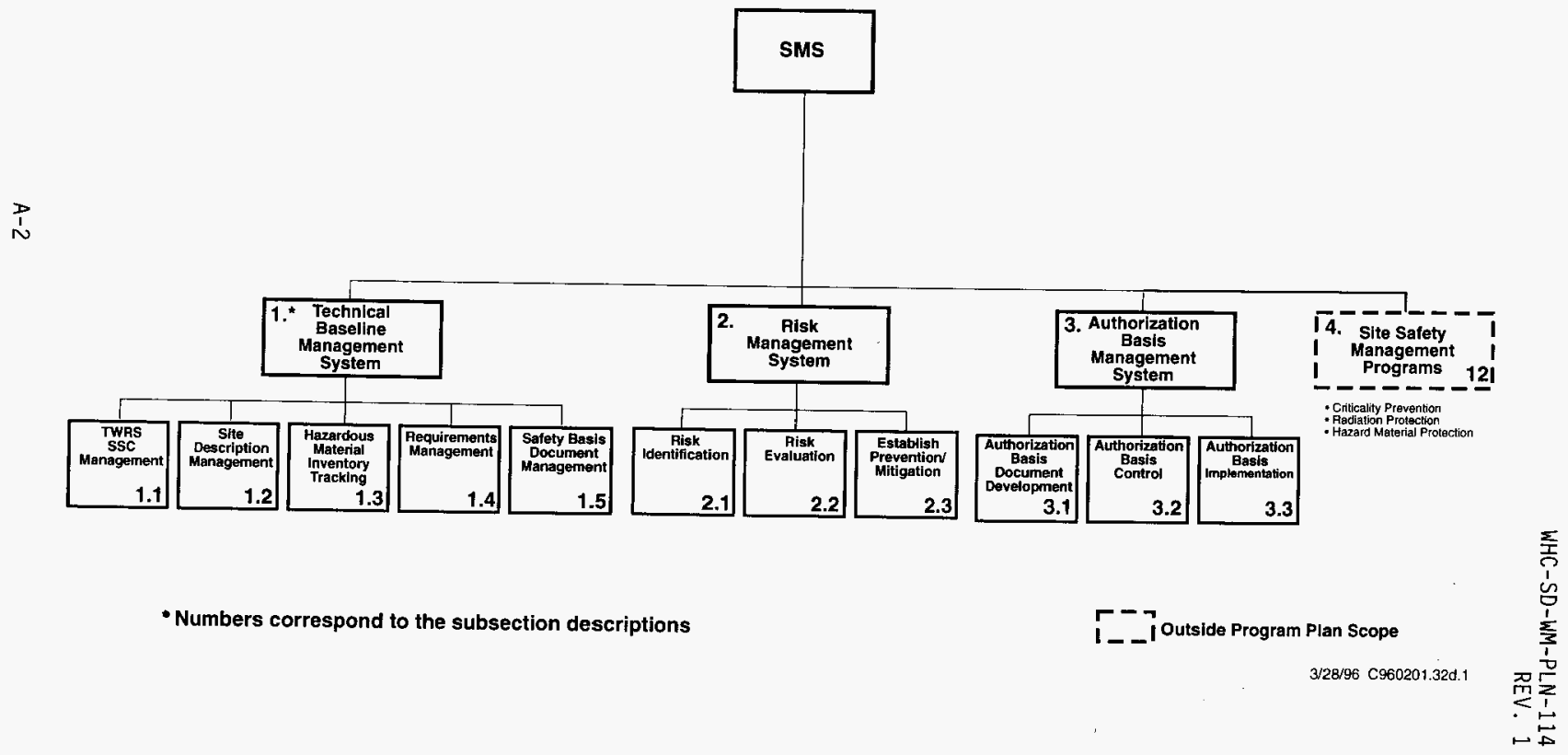


Risk Identification and Authorization Basis Control functions. Inventory Tracking will also ensure that any changes to tank farm hazards will be identified and evaluated before adding new wastes to the tanks.

\subsection{REQUIREMENTS MANAGEMENT}

The Requirements Management function must provide a documented process to identify and allocate requirements (i.e., S/RID and systems engineering functions and requirements) important to the TWRS Safety Management Program. Changes in requirements must be assessed and communicated to affected subsystems. For the Safety Management Program, the WHC-TWRS S/RID that has been prepared, reviewed, and approved, and systems engineering functions and requirements will be used. Relevant portions of the TWRS S/RID will be implemented by the safety management system procedures.

\subsection{SAFETY BASIS DOCUMENT MANAGEMENT}

The Safety Basis Document Management function identifies and manages safety basis documents and develops an appropriate document tracking system. Revisions to the list of documents must be forwarded to the Authorization Basis Control function.

\subsection{RISK MANAGEMENT SYSTEM FUNCTIONS AND REQUIREMENTS}

The Risk Management System is required to: (1) identify potential accidents and accident initiators; (2) analyze the identified hazards and accidents to determine the associated risks; (3) evaluate the risks relative to established guidelines; and (4) determine the appropriate controls to reduce the risk to an acceptable level including defense-in-depth.

\subsection{RISK IDENTIFICATION}

The Risk Identification function must identify accident initiators and establish the processes for performing hazards analyses and accident analyses to determine the frequency and consequence associated with various postulated events. This function must be alerted to actual or proposed changes in the hazards identification (type, quantity, form, process or storage condition, and location) and site characteristics. Changes in frequency or consequence must be communicated to the following functions: Risk Evaluation, Establish Prevention/Mitigation, and Authorization Basis Control. Risks originating outside the scope of TWRS that may affect the functioning of TWRS safety class or safety significant SSCs, or that may initiate accidents within TWRS will be similarly considered.

\subsection{RISK EVALUATION}

The Risk Evaluation function must provide a process to evaluate identified risks against approved risk evaluation guidelines to determine whether any controls are necessary or prudent to reduce the overall risk. Changes in frequency or consequences of the hazards analysis (or accident analysis) or changes in the approved risk evaluation guidelines must be 
communicated to this function. Changes in the level of risk must be communicated to the Establish Prevention/Mitigation and the Authorization Basis Control functions.

\subsection{ESTABLISH PREVENTION/MITIGATION}

The Establish Prevention/Mitigation function must provide a process to determine the appropriate set of SSCs and Administrative Controls required to reduce identified risks making use of the risk evaluation guidelines and implementing appropriate defense-in-depth. Changes in the level of risk associated with identified accidents, and proposed changes to the SSCs and Administrative Controls credited in the analyses must be communicated to this function. Changes in the list of required SSCS and Administrative Controls must be input to the TWRS SSC Management and the Authorization Bas is Control functions.

\subsection{AUTHORIZATION BASIS MANAGEMENT SYSTEM FUNCTIONS AND REQUIREMENTS}

The Authorization Basis Management System is required to develop authorization basis document evaluate and control changes, and implement the authorization basis .

\subsection{AUTHORIZATION BASIS DOCUMENT DEVELOPMENT}

The Authorization Basis Document Development function must provide a process to develop and revise authorization basis documents. Changes to the authorization basis documents must be input to the Authorization Basis Control and the Authorization Basis Implementation functions. This function must maintain a list of authorization basis documents.

\subsection{AUTHORIZATION BASIS CONTROL}

The Authorization Basis Control function must provide a process to screen, evaluate, document, track, and resolve authorization basis changes. A key component of this function is the USQ process. Actual changes as well as proposed changes in the facility SSCs, site description, facility hazards, facility risks, safety basis documents, authorization basis documents, and operating and maintenance procedures must be input to this function. This function must also be alerted to discoveries and occurrences. Changes to the authorization basis must be input to the Authorization Basis Implementation, Authorization Basis Document Development, and the Safety Bas is Document Management functions.

\subsection{AUTHORIZATION BASIS IMPLEMENTATION}

The Authorization Basis Implementation function must provide a process to implement the authorization basis in the appropriate documents and procedures and to develop the requisite training. Changes in the authorization basis documents and classification of SSCs must be input to this function. This function must track the implementation documents and provide a list of these 
documents to the Authorization Basis Control and the Safety Basis Document Management functions.

\subsection{SITE SAFETY MANAGEMENT PROGRAMS}

Numerous other site management programs interface with the Safety Management System. Examples of these programs include prevention of inadvertent criticality; radiation protection; hazardous material protection; radioactive and hazardous waste management; quality assurance; emergency preparedness program; testing, surveillance, and maintenance; operational safety; procedures and training; human factors; provisions for decontamination and decommissioning; management, organization, and institutional safety provisions. Each of these programs must be evaluated to determine its impact on the Safety Management System and to determine when changes to these programs must be communicated to the Safety Management System.

The Site Safety Management Programs (e.g., those programs discussed in Chapters 6 through 17 of the FSAR) are an integral part of the overall safety management system. Those programs are already in place and are governed by WHC policies and procedures which will be reviewed to ensure proper interface with the safety management system procedures developed under this plan. 


\section{APPENDIX B SAFETY MANAGEMENT SYSTEM IMPLEMENTATION FOR A PROJECT}

A key function of the Safety Management System is to control the acceptance of safety documents into the TWRS authorization basis. This control is established through issuing procedures which identify prescribed requirements for the documents and through a review process to assure compliance to those requirements. The Safety Management System must provide direct interface with TWRS plant modifications and projects to ensure that procedural requirements are met and that strategies unique to each modification or project are aimed at successful regulatory approval and change of the authorization basis.

The steps on the following pages discuss the development process for a representative plant modification as depicted in Figure B-1.

A. A desired change to the facility or its operation is identified and the functional requirements and scope are documented.

Tools Required:

- Procedure to identify and document the requirements and scope of a proposed modification.

B. The boundary of the authorization basis modification must be developed and documented. The boundary will be based on the scope of the project and may include some of the existing TWRS configuration. The configuration of the SSCS within the scope of the upgrade will be documented.

Tools Required:

- Procedure to identify and document boundary of modification.

- Procedure to document configuration of SSCs.

- Change control procedure for SSC configuration documents.

- Tracking system for SSC configuration documents.

- Change controi procedure for the above.

C. Based on the scope and requirements of the proposed change, an evaluation of the impact on the existing authorization basis is made through the USQ process. If the results of the evaluation are positive, the process continues at step $C$, otherwise, the negative results are documented and this process stops.

Tools Required:

- USQ Procedure.

D. Based on the boundary of the authorization basis modification, the hazardous material within the scope will be identified and documented.

Tools Required:

- Procedure to document and track hazardous material inventory.

- Change Control procedure for the hazardous material inventory document. 
Figure B.1

\section{Authorization Basis Modification Development for Project (Sample Process)}
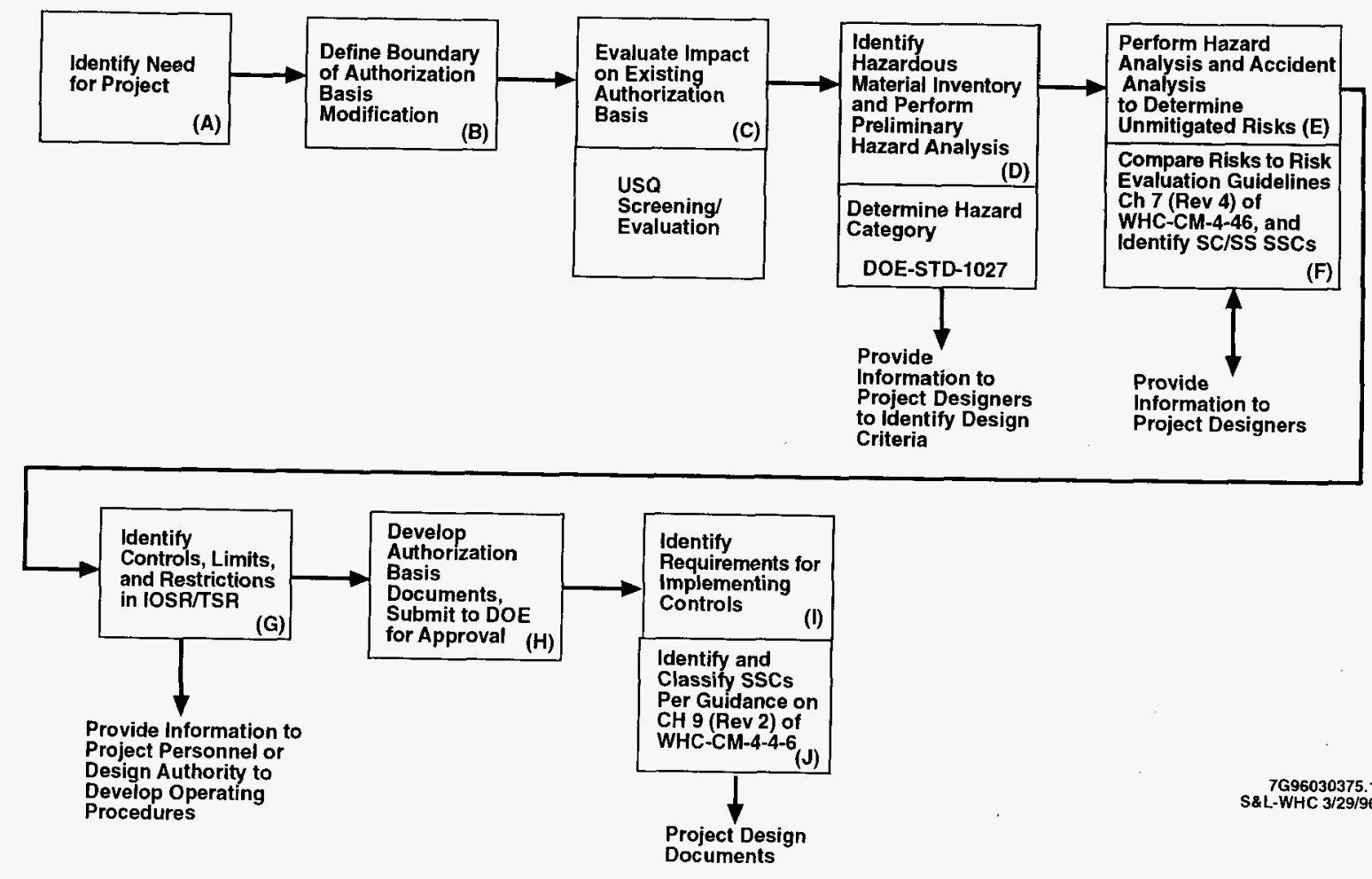
E. The site characteristics and hazardous material inventory will be used to identify the unmitigated risks (i.e., consequences associated with the release of the hazardous material assuming no SSCS and a release probability of 1 ). The unmitigated risks will be reviewed against the risk evaluation guidelines to determine the need for preventive/mitigative controls to reduce the risk. The results will be provided to the SSC designer to determine overall project functional classifications.

Tools Required:

- Procedure to prepare a hazard assessment document.

- Procedure to analyze accident sequences to determine resulting risk.

- Change control procedure for the hazard assessment document.

F. The resulting frequency/consequences of the unmitigated accident analysis are compared to the risk evaluation guidelines. If they exceed the risk evaluation guidelines, preventive/mitigative measures will be developed. The resulting identification of Safety $\mathrm{Cl}$ ass and Safety Significant SSCs will be identified in a design document, engineering calculation notes, and a preliminary hazards analysis (PHA) table. This will initiate a change to the as-built configuration control documents to add the identification of the newly classified SSCs as well as the functions and requirements associated with those SSCs.

Tools Required:

- Procedure to identify and document mitigators and preventers.

- Procedure to conduct safety analyses.

- Procedure to prepare engineering calculation.

- Procedure to compare risks to the risk evaluation guidelines.

G. Based on the selection of the preventers and mitigators, the specification of the controls, limits, and restrictions are identified and documented in IOSR/TSR.

Tools Required:

- Procedure for development and documentation of controls, limits, and restrictions.

- Change Control procedures for IOSR/TSR.

H. The results of the preceding steps will be used to develop authorization basis document revisions. The revisions will be submitted to DOE for approval.

Tools Required:

- Procedure for revisions to the authorization basis (e.g., Interim Safety Basis document).

- Procedure for developing and revising compliance Implementation Plans.

- Procedure for the development and preparation of Authorization Basis documents.

I. Based on the authorization basis documents, requirements will be identified for the implementation of the controls in the facility. 
Tools Required:

- Procedure for issuing and revising 0perating and Maintenance procedures.

- Procedure for conducting Surveillance and In-Service Inspections.

- Procedure for developing training.

J. The result of the selection of the mitigators and preventers will be a list of SSCs that provide safety class and safety significant functions. Based on the allocation of S/RID and systems engineering requirements to the project, the design requirements will be allocated to those SSCs. The results will be issued in project design documents.

Tools Required:

- Requirements A11ocation Procedure(s)

To support the preceding activities, procedures for the identification of Authorization Basis documents and Safety Basis documents must be available. Additionally, tracking systems for Authorization Basis documents, Safety Basis Support documents, Safety Class and Safety Significant SSCs, and As-Built documents must be available. These tracking systems will be used to support the USQ process. Furthermore, a procedure will be implemented that wiTl provide for tracking and statusing all of these steps. 


\section{APPENDIX C BASIS FOR INTERIM OPERATION TASK PLAN}

\subsection{INTRODUCTION}

U.S. Department of Energy (DOE) Order 5480.22, "Technical Safety Requirements," (Reference 1), and DOE Order 5480.23, "Nuclear Safety Analysis Reports," (Reference 2), require the submittal of Implementation Plans (IPs) to achieve compliance with these orders. A Basis for Interim Operation (BIO) must be prepared to establish the interim safety basis for the facility until the Safety Analysis Report (SAR) and Technical Safety Requirement (TSR) documents can be completed which meet the requirements of DOE Order 5480.23 and 5480.22. An Interim Safety Basis (ISB) document (Reference 10) was prepared to satisfy this requirement as proposed in the IP (Reference 12). Guidance for the development of a BIO is provided in DOE-STD-3011-94, "Guidance for Preparation of DOE Order 5480.22 (TSR) and 5480.23, (SAR) Implementation Plans," (Reference 3). The ISB for the Tank Waste Remediation System (TWRS) Facility was prepared and submitted to the DOE for approval prior to issuance of DOE-STD-3011-94 and does not conform to all of the guidance in this standard. In addition, the TWRS ISB has not been adequately maintained as the current authorization basis for the facility, and the Interim Operational Safety Requirements (IOSRS) (References 7, 8, 9, 10) have not been rigorously derived from a comprehensive hazard analysis.

This task plan addresses the work to be performed to prepare a Westinghouse Hanford Company (WHC) approved BIO for the TWRS facility to comply with the requirements of DOE Orders 5480.22 and 5480.23 and DOE Standard DOE-STD-3011-94. This plan reflects the approved Multi-year Program Plan guidance and the changed definition of the location of the maximum exposed individual and risk evaluation guidelines (Ref 15, 16, and 17).

The BIO and its attendant IOSRs will supersede the Interim Safety Basis and become the authorization basis for the TWRS Facility until superseded by the FSAR.

\subsection{TASK DEFINITION}

The purpose of this task is to develop a BIO for the TWRS that will meet the requirements of DOE Order 5480.22 and 5480.23 and DOE Standard DOE-STD3011-94.

Specifically, the format of the TWRS BIO will follow the outline below:

Executive Summary

The Executive Summary will present a summary of the results of the safety analyses including the hazard classification of the facility, safety assurance programs, identified vulnerabilities, compensatory measures, restrictions on interim operations, operational history, and the rationale for why the facility is safe for interim operation. 


\subsection{Introduction}

The introduction will provide the reasons for the BIO and give a brief background about the facility, its current mission, its contribution to the site mission, its past operating history, and scope of the document. The status of the existing authorization basis and associated documentation will also be discussed.

\subsection{Facility Description}

This section will provide a description of the facility; its mission; its processes; and the primary structures, systems, and components (SSCS) that are important to safety. The Facility Description will be the FSAR Chapter 2. The site description will be provided by including Chapter Iof the FSAR.

\subsection{Relevant Operational History}

This section will provide a description of any significant abnormal occurrences and/or accidents along with the compensatory measures that have been implemented or planned. Safety changes to the facility condition subsequent to issuance of the Interim Safety Basis will be summarized. A brief description of any safety related findings from recent Operational Readiness Reviews and/or Inspection Audits will also be discussed. This section of the BIO will include a summary discussion of the supporting documentation that has been developed for the TWRS phenomena currently being studied as open Unresolved Safety question (USQ) issues, and will also contain a discussion of the facility's corrective action plan involving improvements for USQ evaluations.

\subsection{Safety Management}

This section will briefly define the facility's programmatic approach to safety management for workers and the general publjc. Discussions will include management policies; organizational structure and management responsibilities; radioactive and hazardous material waste management; criticality protection; radiation protection; hazardous material protection; training; testing; surveillance; equipment maintenance; conduct of operations; configuration management; quality assurance; provisions for decontamination and decommissioning; experimental review; emergency preparedness; occurrence reporting; work contro1; performance indicators; and the Standards/Requirements Identification Document (S/RID).

\subsection{Safety Analysis}

This section will describe the approach for the hazard classification of the facility as defined in DOE-STD-1027-92 (Reference 5). The Hazards Analysis (HA) method and results will be described. Discussion will include the impact of both normal operations and postulated accident conditions on workers, the general public, and the environment. The dominant accident scenarios will be identified and evaluated quantitatively. Any potential design, procedure, or equipment 
vulnerabilities related to the presented scenarios will be identified and descriptions of the administrative controls, compensatory measures, or restrictions on interim operations implemented as a result of the identified vulnerabilities will be summarized. In addition, this section will describe the methodology and results used to identify those engineered and administrative controls required for safe operation of the facility. A list of safety class and safety significant equipment, and their attendant safety functions, will be presented.

\subsection{Operational Controls}

This section will discuss the operating envelope of the facility including Interim Operational Safety Requirements (IOSRs), restriction on operations, and administrative controls. Discussion will focus on presenting the controls for dominant scenarios. Additionally, safeguards that are considered significant contributors to facility safety from a defense-in-depth perspective will be identified. The IOSRs will be discussed in summary in this section of the BIO and provided in their totality as a separate document.

\subsection{Conclusion}

This section will state the conclusion of the BIO in a short, summary statement.

\subsection{CUSTOMER AND USER IDENTIFICATION}

\subsubsection{Primary Customers}

The customers are the DOE, Richland 0perations Office (RL), the TWRS Tank Farm Transitions Projects (TFTP), TWRS Characterization Project and TWRS Disposal Program organizations.

\subsubsection{Users}

The primary user of the BI0 documentation, including IOSRs, will be the TWRS TFTP, the TWRS Design Authority organization, and the TWRS Safety and Licensing organization.

\subsection{TASK DELIVERABLES}

The task deliverable is a WHC approved TWRS BIO issued to DOE by September 30, 1996 for approval. Supporting documentation will include a completed Hazards Analysis Report, the Interim Operational Safety Requirements, and an interim classification of Safety Class and Safety Significant SSCs. 


\subsection{TASK ACCEPTANCE CRITERIA}

The task acceptance criteria for the BIO are that it must conform with the requirements of DOE Order 5480.22 and 5480.23 , meet the guidelines of DOE Standard DOE-STD-3011-94, and receive WHC approval by the organizations listed below.

- Westinghouse Hanford Company

- TWRS Safety and Licensing

- TWRS Design Authority

- Tank Farm Transition Projects

- TWRS Chief Engineer

- TWRS Safety and Quality Assurance

- WHC Safety and Environmental Advisory Council (SEAC)

- TWRS Vice President and Manager (Final Approval)

\subsection{METHODOLOGY}

\subsection{MAZARD ANALYSIS METHODOLOGY}

Specific information on the hazard analysis methodology is provided in the Tank Waste Remediation System Final Safety Analysis Report Project Plan, WHC-SD-WM-PLN-113, Rev. 0 . To minimize programmatic costs, the TWRS BIO HA team will utilize information generated for TWRS FSAR Chapter 3 analys is as input. Accordingly, the schedule for the BIO is highly dependent upon the completion of FSAR Chapter 3 analysis. Any changes in the FSAR Chapter 3 analys is schedule will cause subsequent delays in the BIO schedule. FSAR Chapter 3 analysis input to the BI0 will include the following:

- Facility Inventory - Provide an inventory of radioactive and hazardous materials (location, type, form, quantity) for TWRS facilities.

- Hazard Identification Tables - Provide a hazard identification table for TWRS facilities and operations.

- Estimate of Frequency, Consequence, and Risk - Provide an estimate of the frequency, consequence, and risk for all receptors (off-site public, co-located, facility worker) and the environment without controls.

- Identify Preventers and Mitigators - Provide a complete 1isting of the administrative and engineering controls used as preventers (reduce the frequency) and mitigators (reduce the consequence) for each event.

- Estimate of Frequency, Consequence, and Risk - Provide an estimate of the frequency, the consequence, and the risk for all receptors (offsite public, co-located, facility worker) and the environment with controls. 
Output from the hazard analysis will include the following:

- Hazard Identification Tables - a comprehensive list of hazards associated with TWRS facilities and operations. The tables will be consistent with the Hazard Identification tables from the FSAR HA effort.

- Hazard Evaluation Table - an event description, cause, frequency, consequence, preventive and mitigative features, and risk results for hazard events associated with TWRS facilities and operations.

- Hazard Evaluation Scenario Discussion - a description of the accident scenario, discussion of frequency with and without controls (including the basis for final determination), discussion of consequences to each receptor with and without controls (including the basis for final determination), discussion of the potential for contamination of the environment (including the basis for final determination), identification of specifically credited engineered features and administrative controls used to arrive at the frequency and consequence with control values.

\subsection{INTERIM OSR METHODOLOGY}

The Interim OSRs will be produced following the methodology described in DOE Order 5480.22 and in the WSRC Integrated Work Process Manual (Reference 14).

\subsection{FUNCTIONAL CLASSIFICATION METHODOLOGY}

The methodology defined in WHC-IP-0842 and the risk evaluation guidelines approved for FSAR will be used in the Hazard Assessment process in selection of safety items.

\subsection{TASK ACTIVITIES}

Major task activities for the TWRS BIO include:

- Completion of the BI0, meeting the requirements in Section 1.1, per the schedule in Section 5.0.

- Completion of the TWRS Functional Classification per the schedule in Section 5.0.

- Completion of IOSRs per the schedule in Section 5.0. 


\subsection{TASK SCHEDULE}

The reference schedule for the TWRS BIO is:

Activity Description

Perform interim functional classification of Safety Class/Safety Significant SSCS.

Prepare IOSRs.

Prepare balance of $B 10$ sections.

Compile HA, interim functional classification, IOSR, and balance of BIO sections into BIO document.

Issue completed BI0 document. $\begin{array}{ll}\frac{\text { Start }}{05 / 30 / 96} & \frac{\text { Finish }}{08 / 02 / 96} \\ 05 / 15 / 96 & 08 / 30 / 96 \\ 05 / 13 / 96 & 08 / 30 / 96 \\ 08 / 16 / 96 & 09 / 30 / 96\end{array}$

09/30/96 Milestone

Begin review of IOSRs.

08/19/96 Milestone

Begin review of completed BIO.

\subsection{TASK QUALITY ASSURANCE PLAN}

Applicable department quality assurance requirements for task deliverables will be implemented consistent with appropriate parts of the WHC Quality Assurance Manual (Reference 11). Quality is ensured by (1) selection of qualified personnel, (2) quality assurance during document preparation, and (3) quality assurance during the document review process.

\subsection{TASK ASSUMPTIONS}

The scope of the BIO will be based on the following assumptions:

- Hazards wi11 be identified, evaluated, and categorized as part of the FSAR task.

- Selection of Safety Class/Safety Significant SSCS is to be performed in accordance with WHC-IP-0842.

- TSR developed as part of the FSAR are to be used as available. If new IOSRs are required, they will be revised in accordance with DOE Order 5480.22 to address the BIO documentation.

- Utilize existing safety documentation to the extent possible.

- Any projects which add to or modify TWRS Facilities will require preparation of amendment packages to the BIO. 


\subsection{REFERENCES}

1. U.S. Department of Energy, "Technical Safety Requirements, "DOE Order 5480.22, Washington D.C., February 25, 1992.

2. U.S. Department of Energy, "Nuclear Safety Analysis Reports," DOE Order 5480.23, Washington D.C., Apri1 10, 1992.

3. U.S. Department of Energy, "Guidance for Preparation of DOE Orders 5480.22 (TSR) and 5480.23 (SAR) Implementation Plans, " DOE-STD-3011-94, Washington D.C., November 1994.

4. Westinghouse Hanford Company, "Hanford Site Tank Farm Facilities Interim Safety Basis," WHC-SD-WM-ISB-001, Rev. 0, Rich1and, Washington, August, 1993.

5. U.S. Department of Energy, "Hazard Categorization and Accident Analysis Techniques for Compliance with DOE Order 5480.23, Nuclear Safety Analysis Reports," D0E-STD-1027-92, Washington D.C., December 1992.

6. Westinghouse Savannah River Company, "Functional Classification of Safety Class and Safety Significant Structures, Systems, and Components, "Manual E7, Procedure 2.25, Aiken, South Carolina, February 1, 1995.

7. Westinghouse Hanford Company, "Single-She11 Tank Interim Operationa] Safety Requirements," WHC-SD-WM-0SR-005, Rev. 08, Richland, Washington, April 3, 1995.

8. Westinghouse Hanford Company, "Double-She11 Tank Interim Operational Safety Requirements," WHC-SD-WM-OSR-016, Rev. 08, Richland, Washington, April 3, 1995.

9. Westinghouse Hanford Company, "Aging Waste Facility Interim Operational Safety Requirements," WHC-SD-WM-0SR-004, Rev. 08, Richland, Washington, April 3, 1995.

10. Westinghouse Hanford Company, "Hanford Site Tank Farm Facilities Interim Safety Basis Volume 1 and Volume 2,"WHC-SD-WM-ISB-001, Rev. 0, Richland, Washington, August 1993.

11. Westinghouse Hanford Company, “Qual ity Assurance Manual," WHC-CM-4-2, Release 83, Richland, Washington, February 15,1996.

12. Westinghouse Hanford Company, "Implementation Plan for DOE Orders $5480.21,5480.22$, and 5480.23," Correspondence No. 9257875, Rich 1 and, Washington, October 28, 1992.

13. U.S. Department of Energy, "Preparation Guide for U.S. Department of Energy Nonreactor Nuclear Facility Safety Analysis Reports," DOE-STD3009-94, July 1994. 
14. Westinghouse Savannah River Company, "Safety Document Integrated Work Process Guideline and Methods (U)," WSRC-RP-95-001, Rev. 0, Aiken, South Carolina, November 30, 1995.

15. Letter from J. Kinzer, RL, to President, WHC, "Direction For Risk Evaluation Guidelines And Offsite Maximum Exposed Individual (MEI) Location," 96-WSD-062, dated May 31, 1996.

16. Letter from A. Sidpara, RL, to President, WHC, "Risk Acceptance Criteria For Tank Farm Operation," \#9502999, dated June 14, 1995.

17. Memorandum from R.Guimond, HQ, to Manager, RL, "Interim Radiological Dose Acceptance Criteria For The Hanford Tank Farms Safety Analysis," dated Apri1 4, 1996. 


\section{APPENDIX D RISK MANAGEMENT}

\subsection{INTRODUCTION}

The risk management 1 ist (RML) describes scenarios that could lead to program failure or significant loss of quality in the final program product. For each scenario, the risk and actions that must be taken to control the risk are identified.

The intent of the RML is to focus on those areas of risk that require intensive management or regular visibility with senior management. Risks are considered more important if any of the following conditions exist:

- Consequences are very serious

- Immediate action is required

- Issue has high visibility from stakeholders or federal government

- Required actions are difficult to coordinate

- Senior management decision is required.

The RML is used by Westinghouse Hanford Company (WHC) management to monitor and track significant risks to the program. Task leads use the RML to bring issues related to their tasks to management attention so that appropriate action can be taken. Management reviews with the task leads and others the status of the risks 1isted in the RML at least biweekly. In the case of the Safety Management System, the Tank Waste Remediation System (TWRS) Engineering Department will review those RML items which are red and critical weekly. In addition, the Vice President, TWRS, is appraised of important items. The RML is also used to review risks with the U.S. Department of Energy (DOE). Attached is a sample RML for the Safety Management Program.

\subsection{SAFETY MANAGEMENT PROGRAM RISKS}

In the development of this plan, several steps have been undertaken to mitigate risks identified. Current key risks include the following.

Risk:

Efforts to complete Tri-Party Agreement projects (e.g., W-030), a Basis For Interim Operations (BIO) and a Final Safety Analysis Report (FSAR) in parallel may result in inconsistent Authorization Basis documents.

Mitigating Strategy:

The project team and BIO team will interface with the SAR team to ensure consistency in the following:

- Hazardous material inventory

- Site characteristics

- Hazards/Accident analyses and results 
- Permanent controls identified with associated availability and reduction factors

The safety documentation for these projects has been reviewed for consistency with the BIO, FSAR analyses and Safety Management System content requirements. Upgrades to these safety documents will be performed as necessary. These projects will utilize the Safety Management System document format to the extent practical depending on the stage of development of each project.

Risk:

The BIO and FSAR approval dates will not meet the authorization basis modification requirements of the projects.

Mitigating Strategy:

The authorization basis for the projects will not be incorporated into the FSAR until after Revision 0 is submitted. The project authorization basis documents will be issued as "stand alone," project and/or activity specific authorization basis upgrades satisfying the format guidance of DOE Standard 3009, as described in Section 2.3.

Risk:

The ISB will need to be modified to support plant projects implementing Tri-Party Agreement milestones and DNFSB commitments.

\section{Mitigating Strategy:}

The authorization basis modification documents for each project will define the boundary of the required authorization basis revision. The modification will cover all activities associated with the project so that reliance on the current ISB will be eliminated or at least minimized relative to the operations being added or modified.

Risk:

The projects are creating authorization basis documents that are inconsistent in terms of content and format. This may not meet third party review criteria.

Mitigating Strategy:

The safety documentation for these projects has been reviewed for consistency with the FSAR analyses and safety management system content requirements. Upgrades to these safety documents will be performed as necessary. These projects will utilize the Safety Management System document format to the extent practical depending on the stage of development of each project. 
Risk:

Some TWRS project safety analyses are being developed using different definitions for the location of the MEI and risk evaluation guidelines than the TWRS BIO and FSAR per DOE guidance provided in reference 15 of Appendix $C$. These differences have the potential to generate different functional classifications and differing control requirements within TWRS.

\section{Mitigating Strategy:}

WHC will implement the more conservative control requirements for a particular SSC or administrative control should a case arise that differing control requirements are generated by these differences in MEI and REG. In addition, a parametric study of the impacts of changed MEI and REG is being performed to identify any areas of significant impact arising from these changes. 


\section{APPENDIX E COST AND SCHEDULE SUMMARIES}

The provisional baseline cost and schedule data provided in Revision 0 have been modified to reflect approval of the Multi-Year Program Plan guidance. The cost details by work breakdown structure (WBS) element and for Fiscal Year 1996 are shown in Table 6-1. 


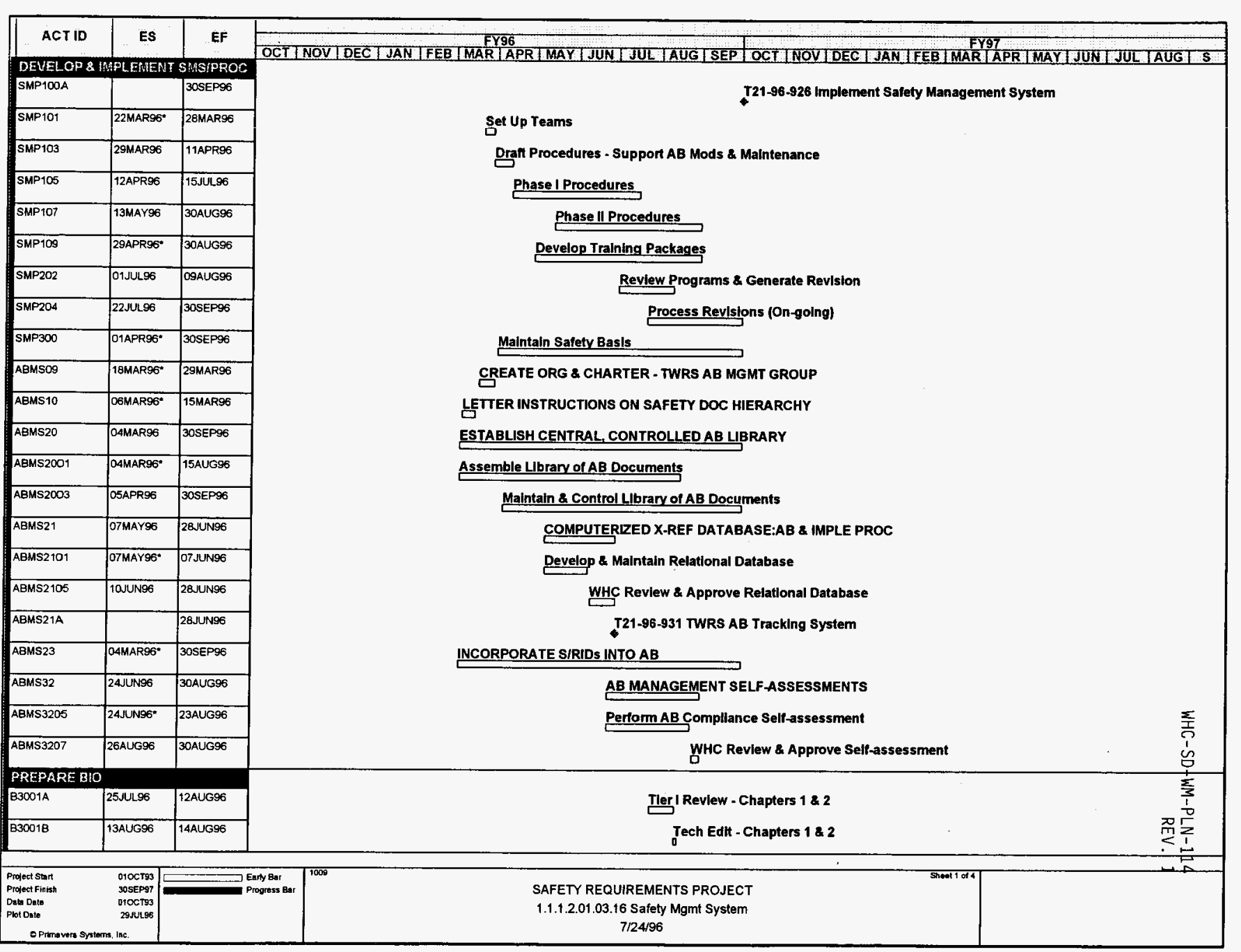




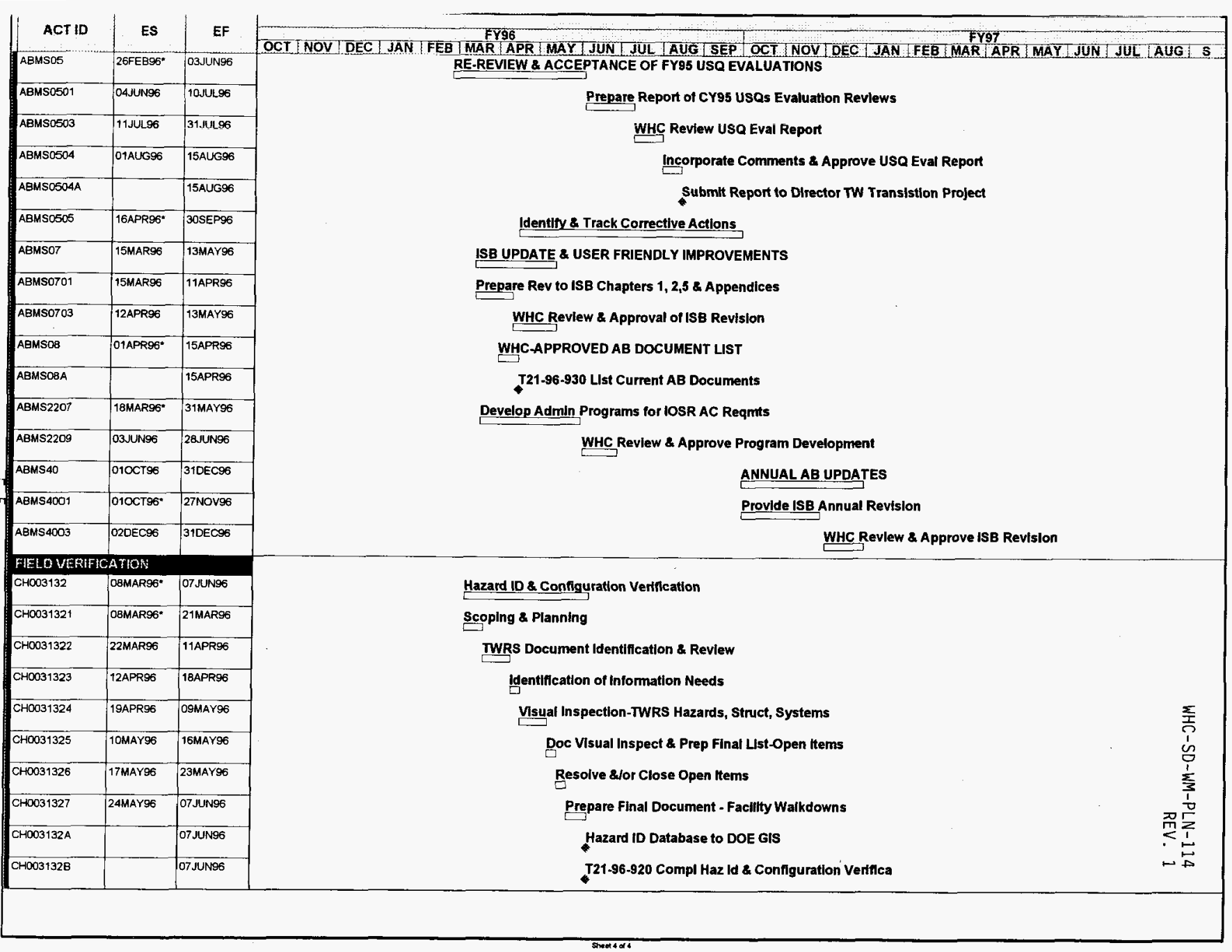




\section{DISTRIBUTION SHEET}

\begin{tabular}{|c|c|c|c|c|c|}
\hline \multirow{2}{*}{$\begin{array}{l}\text { To } \\
\text { Distribution }\end{array}$} & \multirow{2}{*}{\multicolumn{3}{|c|}{$\begin{array}{l}\text { From } \\
\text { TWRS Safety \& Licensing }\end{array}$}} & \multicolumn{2}{|l|}{ Page 1 of 1} \\
\hline & & & & \multicolumn{2}{|c|}{ Date $07 / 31 / 96$} \\
\hline \multicolumn{4}{|c|}{ Project Title/Work Order } & \multicolumn{2}{|l|}{ EDT No. } \\
\hline \multicolumn{4}{|c|}{ TWRS Safety Management Program Plan, WHC-SD-WM-PLN-114, Rev. 1} & \multicolumn{2}{|c|}{ ECN No. 189867} \\
\hline \multicolumn{2}{|c|}{ Name } & $\begin{array}{c}\text { Text } \\
\text { With All } \\
\text { Attach. }\end{array}$ & Text Only & $\begin{array}{l}\text { Attach./ } \\
\text { Appendix } \\
\text { Only }\end{array}$ & $\begin{array}{c}\text { EDT/ECN } \\
\text { Only }\end{array}$ \\
\hline
\end{tabular}

R. F. Bacon

R. 3. Cash

M. L. Cowen

G. L. Dunford

S. J. Eberlein

L. F. Ermold

R. W. Foley

G. R. Franz

J. W. Hagan

A. H. Hansen

J. O. Honeyman

J. J. Klos

E. J. Krejci

C. E. Leach

E. J. Lipke

G. A. Meyer

R. S. Popielarczyk

J. G. Propson

D. A. Raap

A. L. Ramble

D. P. Reber

H. E. Rew

W. E. Ross

O. M. Serrano

J. P. Sloughter

C. L. Sohn

F. 0. Strankman

J. D. Thomson

J. E. Truax

A. M. Umek

T. C. Varljen

J. H. Wicks

R. D. Wojtasek

Project Files

Central Files (Original +2)

Extra (20)

\begin{tabular}{|c|}
\hline 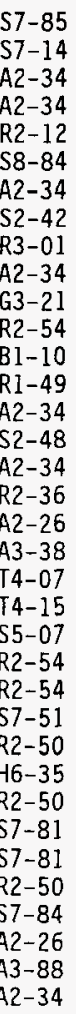 \\
\hline
\end{tabular}

